\title{
3.4 Соціальний капітал як ресурс регіонального розвитку
}

Поняття «позаекономічні інститути» в економічній науці не нове, хоча традиційно воно застосовується в контексті соціологічного аналізу для дослідження соціокультурних, етичних, правових і політико-ідеологічних правил та норм суспільної поведінки. Водночас у сучасному суспільстві економічна діяльність регулюється не тільки економічними інститутами, а й позаекономічними. Регулятивний принцип, закладений у системі моральних норм, соціальної поведінки, культурних традицій, звичаїв, об'єктивно «накладається» на поле економічної поведінки.

Формування позаекономічних інститутів у період трансформації соціально-економічних відносин впливає на відтворення соціального капіталу на мікро-, мезо- та макрорівнях. У свою чергу соціальний капітал здійснює зворотній вплив на систему соціально-економічних відносин у суспільстві за допомогою своїх складових, а саме: соціальних мереж, норм та цінностей, довіри. Тому відтворення соціального капіталу за допомогою позаекономічних інститутів має суттєве значення у стабілізації соціально-економічного розвитку.

За останні десятиліття трансформаційні процеси в економіці набули особливої інтенсивності, насамперед це стосується руху національної економіки до соціально-економічних моделей суспільного відтворення. У цьому відношенні теоретичні та прикладні питання визначення змісту, структури, ролі та місця позаекономічних інститутів у відтворенні соціального капіталу об’ єктивно виступають на перший план.

Фундаментальними дослідженнями проблеми соціального капіталу займалися вчені зі світовим ім'ям: Г. Беккер, Р. Берт, П. Бурдьє, Т. Веблен, О. Вільямсон, У. Гамільтон, Дж. Гелбрейт, М. Грановеттер, Дж. Джонсон, Дж. Коммонс, Р. Коуз, Дж. Коулман， Н. Лін， Г. Лоурі， К. Мітчел， Д. Норт, Р. Патнем, А. Портес, У. Ростоу, Ф. Фукуяма, Л. Харрис, Д. Хікс та ін.

Теоретичне обгрунтування поняття економічних та позаекономічних інститутів закладено у працях Л. Алексеєнка, 3. Атаманюка, В. Базилевича, 
Д. Верби, В. Гейця, Ю. Зайцева, Г. Зборовского, М. Іващенка, Р. Капелюшнікова, Т. Кричевської, П. Леоненка, В. Савчука, Є. Смірнова, В. Тамбовцева, А. Шастітко, В. Якубенка та ін. Дослідження соціального капіталу представлено у працях С. Барсукової, 3. Галушки, О. Демченко, Л. Долгової, Н. Ларіонової, Л. Лебедевої, І. Малого, В. Радаєва, В. Тітова. Соціальну ренту розглядали такі науковці, як Н. Апаріна, Є. Діскін, М. Курбатова.

Проте аналіз наукових досліджень свідчить, що роль та місце позаекономічних інститутів у відтворенні соціального капіталу досліджено недостатньо. Так, недослідженим залишається економічний підхід у комплексі позаекономічних інститутів (правових, політичних, ідеологічних, етичних) та $є$ невизначеним вплив позаекономічних інститутів на конвертацію соціального капіталу та утворення соціальної ренти. Актуальність зазначених питань, їх важливість і практична значущість обумовлюють необхідність додаткових досліджень.

Дослідження поняття «позаекономічні інститути» проведемо за допомогою категорій одиничного, особливого й загального.

Вивчення категорій «одиничне», «особливе», «загальне» має велике значення для людського пізнання та розвитку. За їх допомогою можна доступніше пояснити $\mathrm{i}$ дослідити трансформаційні процеси сучасного суспільства. «Весь світ складається з нескінченої множини предметів, процесів, явищ, властивостей, відношень. У кожному є ознаки, що відрізняються від ознак інших предметів, явищ і роблять їх неповторними, єдиними у своєму роді. Такі ознаки називають одиничними. Проте в кожному предметі є ще й ознаки подібності чи тотожності з ознаками інших предметів або явищ - їх називають загальними. Від категорій одиничного й загального відрізняють категорію особливого, яка виражає діалектичний взаємозв'язок загального і одиничного. Категорія особливого має відносний характер. Вона виступає то як загальне стосовно одиничного, то як одиничне стосовно всезагального. Ця категорія виражає різні сторони і форми прояву загальних закономірностей в окремих 
речах, явищах». Діалектика цих категорій (одиничне, особливе, загальне) зводиться до того, що різниця між ними умовна, вони можуть взаємоперетворюватись одна в одну.

У нашому випадку загальним будуть виступати всі комплекси позаекономічних інститутів (правові, політичні, ідеологічні та етичні); особливим - соціальний капітал; одиничним - соціальні мережі, довіра, норми та цінності (рис. 1.).

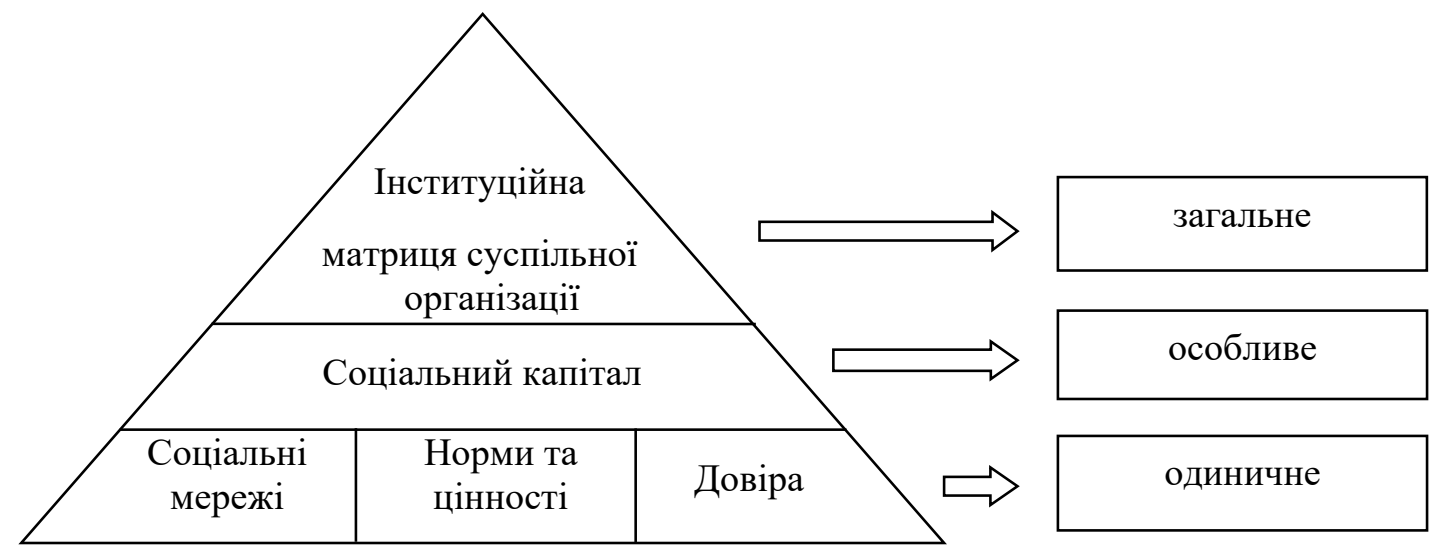

Рис. 1. Загальне, особливе, одиничне при дослідженні позаекономічних інститутів

Джерело: розроблено автором

У суспільстві немає явищ, які б складалися тільки з окремих ознак, будь-то одиничні, чи загальні, так як кожне явище являє собою єдність одиничного й загального, яка виражається категорією «окреме».

Категорія «окреме» виражає конкретне явище, яке об'єднує одиничні й особливі, загальні ознаки. У нашому дослідженні «окремим» буде виступати соціальна рента, яка й об’єднає «одиничне» (соціальні мережі, довіру, норми та цінності), «особливе» (соціальний капітал) та «загальне» (позаекономічні інститути).

Будь-яка система має свою структуру, кожен елемент якої взаємопов'язаний між собою та утворює єдине ціле. Система людських відносин будується за допомогою позаекономічних інститутів, у результаті їх взаємодії з людиною відбувається відтворення соціального капіталу. Саме завдяки позаекономічним 
інститутам, які формують систему відносин людей, основою (каркасом) якої буде виступати інституційна матриця.

У науковій літературі терміном «інституційна матриця» [138, с. 54] послуговуються тоді, коли автори хочуть позначити комплекс зазвичай не пов'язаних між собою конкретних сфер як щось єдине. Спробуємо застосувати цей термін в економічній теорії для позначення позаекономічних інститутів.

Інституційна матриця має здатність до самовідтворення і забезпечує історичну стійкість інститутів відносно різних впливів. Якщо інституційна матриця - це загальне, то особливе - це соціальний капітал. I тільки на одиничному рівні ми розглянемо позаекономічні інститути конкретно, а на особливому всі ці позаекономічні інститути і складатимуть соціальний капітал. Вигода від володіння соціальним капіталом зображена в «окремому»- соціальна рента (рис. 2).

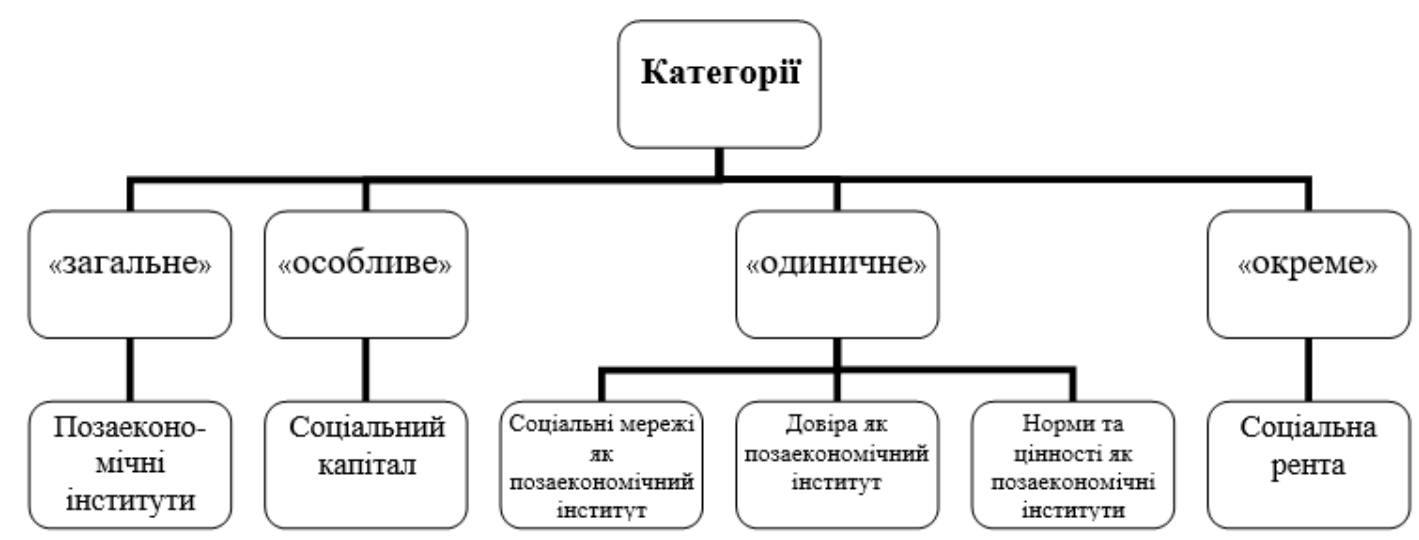

Рис. 2. Інституційна матриця позаекономічних інститутів Джерело: розроблено автором

Дуглас Норт припускав, що своєрідна інституційна матриця утворює стійку структуру в кожному суспільстві і складається із системи інститутів конкретного суспільства. На його думку, суспільство має властиву лише йому інституційну матрицю, що була історично сформована.

С. Г. Кірдіна загалом «інституціональну матрицю» визначає як логічно узагальнені ті різноманітні реальні зв'язки та інститути, які можна спостерігати в соціальному житті. Це юридичні та життєві норми, правила і санкції, 
процедури погоджень і закони, традиції і звичаї, організації та законодавчі акти тощо $[137$, с. 90]. С. Г. Кірдіна схематично зображує так інституційну матрицю (рис. 3), яка показує, що базові інститути утворюють своєрідну внутрішню арматуру, жорстку структуру, «стягуючу» головні підсистеми суспільства в цілісне утворення, що не дозволяє суспільству розпастися. Іншими словами, інституційна матриця - це форма суспільної інтеграції в основних, значущих сферах життєдіяльності соціуму - економіці, політиці та ідеології [139]. На іiі думку, основною моделлю «базових суспільних інститутів» є інституційна матриця, що з'явилася за часів створення перших держав, які являли собою стійкі людські спільноти. Нові інституційні структури, що з'являються з часом, тільки розвивають і збагачують цю первинну інституційну матрицю. Саме вона забезпечує спільне функціонування економіки, політики та ідеології [139]. На думку О. Е. Безсонової і С. Г. Кірдіної, соціальна реальність - це сукупність трьох сфер: ідеології, політики, економіки; під соціальною реальністю вони розуміють відповідні цим сферам підсистеми інститутів.

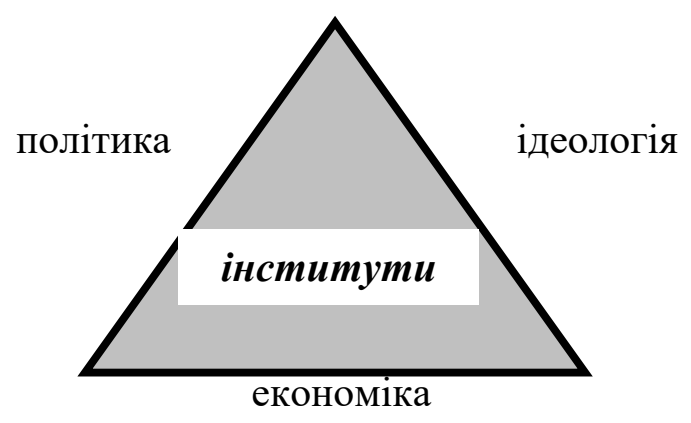

Рис. 3. Схематичне представлення інституційної матриці [139]

Відповідно до принципу домінантності базисних інститутів матриці, який виконується в суспільстві, у соціально-економічній системі панують 3 типи інститутів цієї матриці. Оскільки інституційна матриця $є$ цілісною, то перевага певного базисного інституту матриці зумовлює домінування в суспільстві всіх інших типів інститутів. Комплементарні інститути з альтернативною матрицею можуть також діяти, але як допоміжні, оскільки їх обмежують базисні інститути [141, c. 56-60]. 
O. Е. Безсонова i C.Г. Кірдіна визначають інституційну матрицю як систему економічних, політичних та ідеологічних інститутів, що знаходяться у взаємно однозначній відповідності. С. Г. Кірдіна відділяє абстрактні соціальні форми («соціальні факти») від конкретних фактів і явищ («соціальної реальності»). Інституційні матриці вона розглядає як абстрактні втілення соціальної реальності, а базові інститути - як сутнісні зв'язки між основними сферами людської діяльності в суспільстві [140, с. 56], на відміну від гнучких інституційних форм. У нашому дослідженні ми не будемо розглядати «базові інститути» в концепції О. Е. Безсонової і С. Г. Кірдіної інваріантами, оскільки це не дасть бажаного результату в пошуку та розвитку тих позаекономічних інститутів, які б забезпечили процес відтворення соціального капіталу.

I. Г. Філіппова вважає, що інституційна матриця справді інваріантна, але не за конкретною формою існування утворюючих іiі інститутів, а за їхньою суттю; базисні інститути, що формують основу системи, - це системоутворюючі інститути власності, влади, управління і праці. У будь-якому своєму конкретному втіленні вони визначають усю сукупність конкретних форм соціальних інститутів (а інших інститутів, крім соціальних, бути не може, оскільки інститути - це рамки соціальних взаємодій).

На наш погляд, для більш продуктивного аналізу позаекономічних інститутів та можливості грунтовніше розкрити нашу проблему необхідно дослідити формальні (формальні обмеження) i неформальні правила (неформальні обмеження).

«Класик» нового інституціоналізму, лауреат Нобелівської премії» (1993) Д. Норт вважав, що «інститути - це створені людиною обмеження, які структурують політичні, економічні і соціальні взаємодії» або як «правила, механізми, забезпечуючи їх виконання, і норми поведінки, які структурують повторюючи взаємодії між людьми» [163, с. 73]. Інститути, як зазначає автор, це «правила гри» в суспільстві, або, висловлюючись по-іншому, створені людиною обмежені рамки, які організовують взаємовідносини поміж людьми». I далі: «... вони створюють структуру спонукальних мотивів людської взаємодії 
- будь-то в політиці, соціальній сфері чи економіці» [164, с. 17]. Значення інститутів полягає в тому, що вони обмежують поведінку людей і, відповідно, роблять іiі більш передбачуваною і, можливо, якоюсь мірою менш затратною.

Інститути виникають та існують тільки завдяки тому, що вони є умовними і в результаті впливають на перебіг процесів взаємодії людей, а в подальшому і на життєдіяльність суспільства. Тому саме інститути як сукупність формальних і неформальних норм та правил є тим середовищем, де реалізуються економічні інтереси та закони. Водночас інститути, як фактори ідеологічного, культурного, духовного характеру, формують сутність економічного механізму ринкової економіки.

Д. Норт визначив, що інститути - це «правила гри», які бувають двох видів: формальні і неформальні.

Формальні інститути (обмеження), зазначає Д. Норт, - це правила, вигадані людьми і які є продуктом свідомого людського задуму [164, с. 18]. Вони створюються навмисно, легко фіксуються у вербальній формі і виступають як визначені обмеження. Це писані правила, наприклад Конституція України, законодавчі акти, нормативи та інше.

Неформальні інститути $[105$, с. 40 , с. 49 , с. 79 , с. 143 , с. 176] раніше досліджували у країнах з позиції основних, а не додаткових елементів соціальноекономічного порядку. Та згодом стало відомо, що навіть економіка розвинутих країн також підлягає впливу неформальних компонентів.

Неформальні інститути (неписані правила) - це суспільні умовності і кодекси поведінки, які не зафіксовані в письмовій формі, але які спонукають (змушують) індивіда вести себе відповідно до «правил гри».

Неписані правила, за Д. Нортом, лежать глибше формальних правил i доповнюють їх. «Неформальні обмеження, втілені в звичаях, традиціях i кодексах поведінки, набагато менш сприйнятливі до свідомих людських зусиль» [164, с. 21]. Це - цілий культурний пласт, результат тисячолітнього розвитку народів (спадщина предків): їх звичаїв, традицій, морально-етичних норм поведінки, які захищені так надійно, як і формальні правила. 
А. Аузан неформальні правила трактує як правила, що існують у пам'яті учасників різних соціальних груп, гарантом яких виступає будь-який учасник групи, який побачив їх порушення [134, с. 34].

Між іншим, неформальні правила, якщо вони за період довгострокової практики взаємовідносин роблять економіку ефективнішою, дуже часто трансформуються потім у формальні інститути. I навпаки, ефективний набір формальних правил робить ефективним і неформальні правила.

Неформальні правила є досить складними в описі. Люди, притримуючись ïx, цим самим задають певні рамки спільній діяльності, а також за допомогою неформальних правил люди структурують свої взаємовідносини.

В умовах, коли виникають принципово нові формальні правила, суспільство продовжує зберігати свої старі звичаї. Неформальні правила швидко не змінюються.

Д. Норт звернув увагу на те, що більшість культурних змін носить поступовий характер. Якщо цього не відбувається, то в суспільстві виникає напруження між зміненими формальними правилами $\mathrm{i}$ збереженими неформальними обмеженнями. Неформальні обмеження виникають 3 інформації, яка передається 3 покоління в покоління, і виступає частиною культури суспільства» [164, с. 57-66]. Неформальними обмеженнями, важливими для людства i, зокрема, людини, є чесність, порядність, довіра, повага, самоповага, авторитет, репутація.

Д. Норт виділяє, крім формальних і неформальних обмежень, ще й третю складову - примус та його механізми, що забезпечують дотримання правил (суди, міліція, керівництво).

Д.Норт у книзі «Інститути, інституціональні зміни і функціонування економіки» (1997) запропонував класифікацію формальних «правил» (табл. 1.). Перший і найвищий рівень обіймає конституція, за допомогою якої є можливість встановлювати будь-які інші правила. Далі - законодавчі акти та закони, постанови, розпорядження. На третьому рівні - індивідуальні контракти. За такої 
організації формальних правил інститути знижують трансакційні витрати, роблять поведінку людей передбачуваною та знижують невизначеність.

Таблиия 1.

Рівні класифікації формальних «правил» (за Д. Нортом)

\begin{tabular}{|c|l|l|l|}
\hline Рівні & «Правила» за Д. Нортом & \multicolumn{3}{|c|}{ Значення } \\
\hline I & Політичні (Конституція) & $\begin{array}{l}\text { - фіксують ієрархічну структру держави, } \\
\text { визначають структуру і механізм } \\
\text { прийняття рішень та механізм контролю } \\
\text { виконання даних рішень; }\end{array}$ \\
\hline II & $\begin{array}{l}\text { Економічні (законодавчі } \\
\text { акти парламенту та } \\
\text { закони) }\end{array}$ & $\begin{array}{l}\text { визначають основу появи прав } \\
\text { власності, мають свої продуктом не } \\
\text { тільки права, але й обов'язки так як в } \\
\text { процесі взаємодії одні агенти повинні } \\
\text { дотримуватися права інших; }\end{array}$ \\
\hline III & Контракти & $\begin{array}{l}\text { правила, які впорядковують обмін між } \\
\text { двома агентами на основі специфікації } \\
\text { обмінюваних прав і взятих на себе } \\
\text { обов’язків. }\end{array}$ \\
\hline
\end{tabular}

Джерело: розроблено автором на основі [164]

Перший рівень організації формальних «правил» обіймає Конституція (політичні правила), яка виступає основою при формуванні інших правил. Другий рівень - економічні правила: законодавчі акти та закони, постанови, розпорядження як на рівні держави, так і на регіональному та місцевому рівнях. Третій рівень посідають індивідуальні контракти. При такій вдалій ієрархії формальних «правил» забезпечується стабільність інституціональної структури суспільства за допомогою передбачуваності поведінки людей і зниження невизначеності і трансакційних витрат. Розподіл трансакційних витрат між користувачами інформації, що опосередковує процес взаємодії (трансакцію), дає змогу зекономити на масштабах діяльності. Розмір вигод від обміну залежить від величини трансакційних витрат і від розподілу їх між суб' єктами обміну.

Конституція (політичні правила) визначає узагальнену структуру прийняття політичних рішень і здійснює контролюючу функцію. Економічні правила 
(законодавчі акти парламенту та закони) встановлюють права власності, що лімітують доступ інших до ресурсів, які характеризують засоби застосування власності й отримання прибутку. Контракти впорядковують процедуру обміну.

Важливим критерієм ефективності неформальних обмежень є те, як люди виражають свої переконання, слідують їм і добиваються змін у законодавстві 3 нульовими або дуже незначними витратами [164, с. 65]. Якщо співробітництво і неформальні правила такого співробітництва допоможуть знизити витрати взаємовідносин, то такі норми будуть затверджуватися в суспільстві і через деякий час можуть перерости у формальні правила.

Неформальні правила досить живучі, і зміна їх пов’язана з культурними характеристиками системи. Хоч і в новій інституційній економічній теорії неформальні інститути найчастіше розглядають як доповнення до формальних змін, при зміні формальних правил інколи неформальні норми, які збереглися, виявляються несумісними $з$ ними. У результаті цього розвивається конфлікт правил.

Розв’язання цього конфлікту Д. Норт описав так: «... 3 плином часу неефективні інститути вимирають, а ефективні - виживають, і тому відбувається розвиток більш ефективних форм організації» [164, с. 120]. Отож, на думку Д. Норта, основною тенденцією розвитку інститутів є тенденція до розвитку стабільного порядку, тому що головна задача інститутів полягає у зменшенні невизначеності людських дій. Узагальнюючи систему визначень інститутів, яку дає Д. Норт, можна сказати, що інститути - це сукупність правил і норм, які люди накладають на свої відносини, визначаючи стимули і механізми контролю, що поряд із бюджетними, ресурсними, технологічними й іншими обмеженнями окреслюють межу вибору в діяльності економічних суб’єктів.

Формальні і неформальні інститути виконують специфічні функції і $\epsilon$ елементами системи суспільної організації економічної діяльності. Тому необхідно структуризувати інституціональне середовище на:

1. Підсистему нормативних інститутів (норми, правила). Вони складають загальні стереотипи мислення, обмеження поведінки, ділову та корпоративну 
етику, які під дією особливостей кожної сфери господарської діяльності трансформуються у специфічні форми поведінки економічних суб'єктів споживчі, трансакційні, виробничі. Координація дій і досягнення необхідного взаємовигідного результату забезпечується завдяки спільним основам поведінки економічних суб’ єктів.

2. Організаційно-технічну підсистему (установи, організації). Вона виділяє організаційні структури економічних суб’єктів та їх організаційно правові форми. Кожна з виділених підсистем інституційного середовища поділяється на формальну і неформальну складову.

О. О. Беляєв вважає, що формальні правила (юридичні закони) можуть змінюватись одномоментно. У системі інститутів вони утворюють свого роду зовнішній, поверховий шар, здатний стрімко змінюватися. Неформальні інститути (узвичаєні стереотипи та норми поведінки, що вкоренилися в індивідуальній і суспільній свідомості), які становлять найміцніше ядро системи інститутів, повільно й важко піддаються змінам. Неформальні норми та правила через усі зміни навколишнього середовища трансформуються поступово, у міру формування альтернативних моделей поведінки організацій та індивідів згідно 3 новим сприйняттям ними вигід і витрат [125, с. 93]. Формальні та неформальні інститути визначають економічну поведінку і результати, формують економічну політику відповідно до економічних інтересів суб'єктів господарювання. Зміни інститутів змінюють характер і сприйняття економічної політики [125, с. 94].

Запропонована В. Каспером інституційна матриця $\epsilon$ детальним доповненням до звичної класифікації інститутів (формальні та неформальні), автор для них виділяє такі класифікаційні ознаки (рис. 4):

- сформовані інститути на добровільних засадах або за допомогою примусу;

- інститути створені еволюційним шляхом (спонтанно) або штучно, на договірній основі;

- санкції, які застосовуються спонтанно, з урахуванням соціальних норм поведінки (так звана зворотна реакція суспільства), або навмисно, 
керуючись офіційно хваленими процедурами в межах окремих груп, наприклад професійний кодекс поведінки [261].

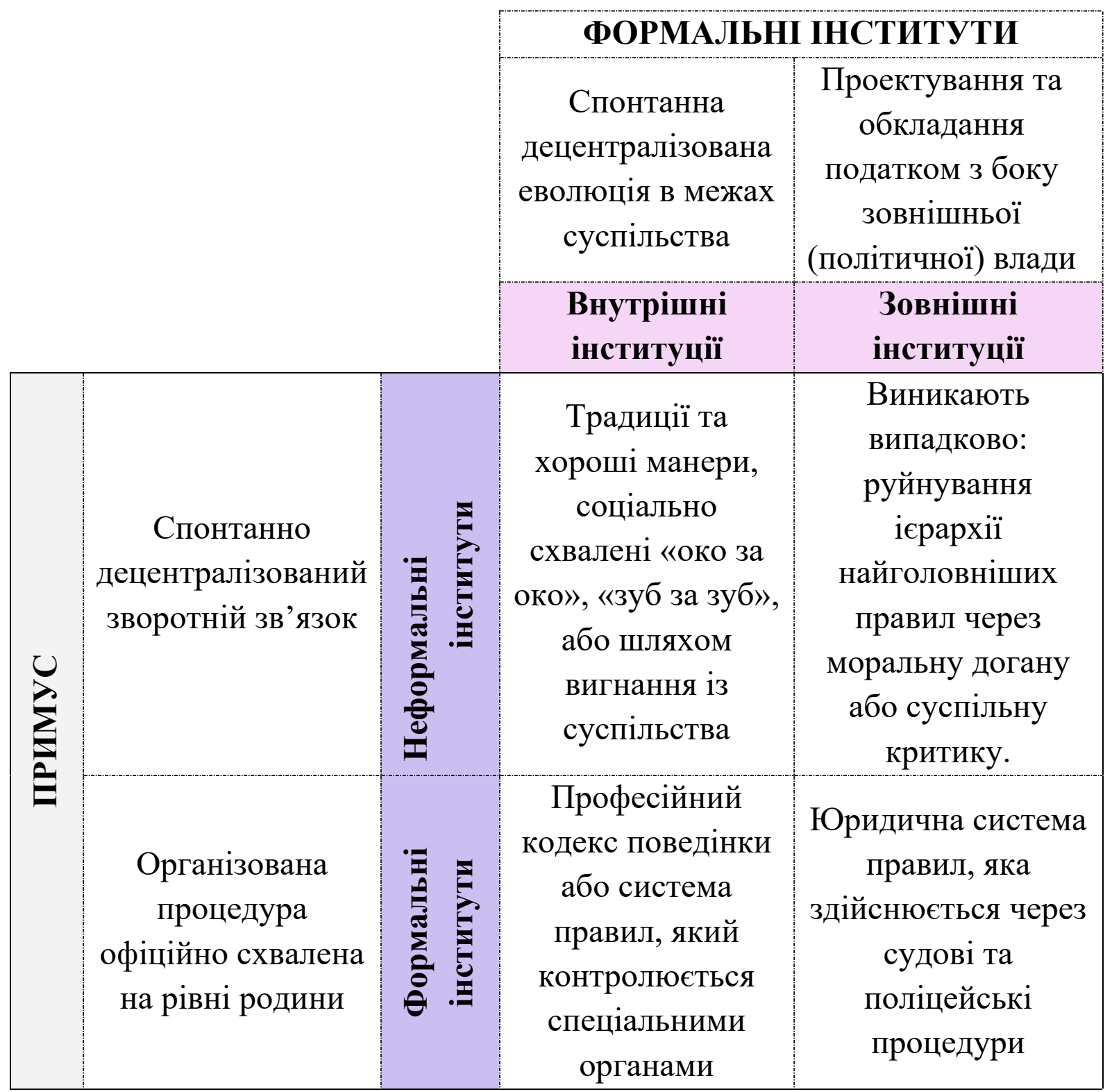

Рис. 4. Класифікація інститутів, яка базується на субординації правил, методів їх створення, а також примусових санкцій [261]

Представники неоінституціоналізму У. Ростоу, Дж. Гелбрейт вважають, що головним у забезпеченні поступального розвитку суспільства $є$ раціональна взаємодія інститутів - держави, підприємства, власності, капіталу, грошей, сім’ї, профспілок та інституційних норм (правил), звичок, інстинктів, традицій тощо. 
Кожен інститут нерозривно пов' язаний із соціальною взаємодією. Інститути виникають у процесі соціальних взаємодій, вони є взаємодією, вони мають своїм результатом взаємодію [115]. Інститути як чинники політичного, правового, етичного, ідеологічного характеру формують зміст економічної системи, вони $\epsilon$ тією субстанцією, яка впливає на характер економічного розвитку.

Соціально-економічні інститути поділяються на економічні та позаекономічні. Розглянемо їх структуру (рис. 5). Економічні (базисні) включають у себе такі інститути: власності, влади, управління, праці [236], а позаекономічні - правові, політичні, ідеологічні та етичні інститути.

Вивчаючи неформальні інститути та регулюючі ними економічні відносини, можна сказати, що це відбувалося шляхом виділення неформального компонента економіки «як феномена особливого роду, що носить загалом маргінальний характер, до визнання універсальності неформальних відносин, їх нерозривного і природного зв'язку з формальною економікою» [209].

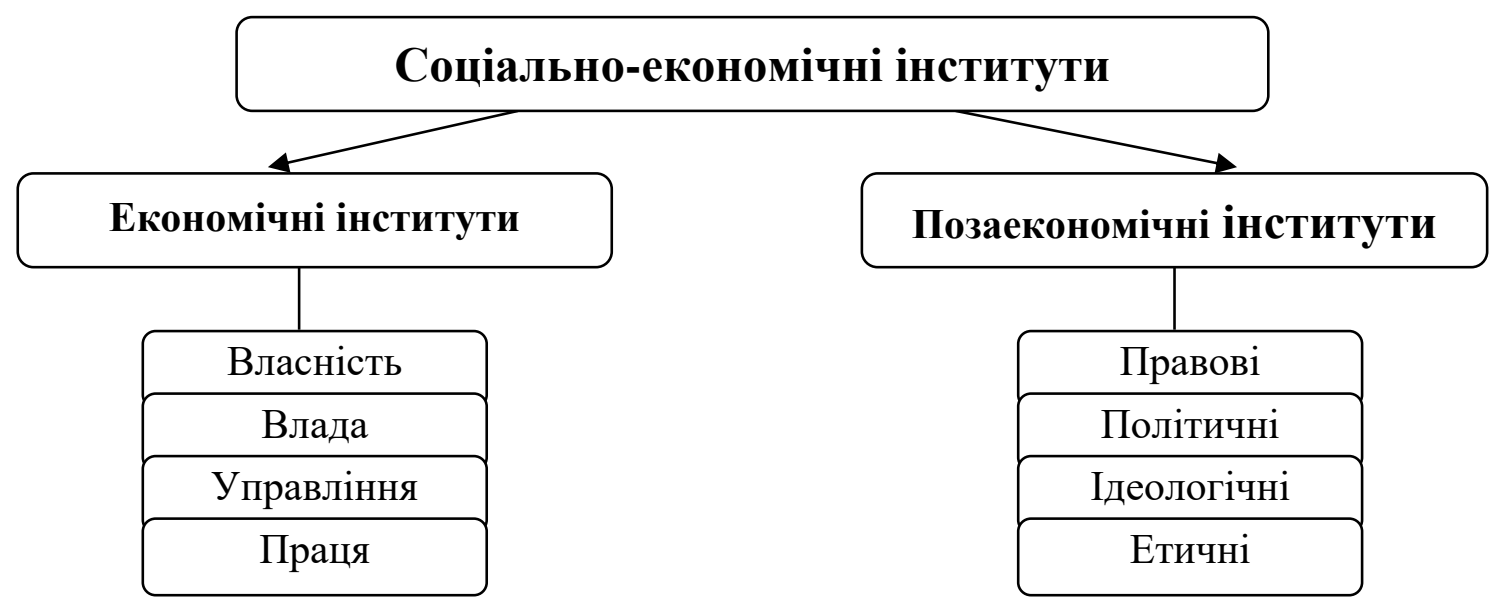

Рис. 5. Структура соціально-економічних інститутів

Джерело: розроблено автором для зображення структури економічних інститутів, використано [236]

Економічні, юридичні, політичні та соціальні рамки взаємодії між людьми поділяються на формальні правила гри - закони, нормативні акти і неформальні - звички, звичаї, традиції. Утворення формальних інститутів відбувається в результаті дій соціальних груп і визнається державою як нормативно правовий 
акт, закон та інше. А неформальні інститути утворюються спонтанно в результаті дій економічних суб’єктів.

Отже, соціально-економічні інститути поділяються на:

- формальні;

- неформальні;

- спонтанні.

На нашу думку, триєдинство суспільства, запропоноване С. Г. Кірдіною, що включає в себе економічну, політичну та ідеологічну підсистеми, є допустимим у соціологічних дослідженнях, проте не в політекономії. Тому каркас інституціональної матриці суспільної організації (рис. 6) формують такі позаекономічні інститути: правові, політичні, ідеологічні, етичні. Завдяки цим позаекономічним інститутам, що утворюють систему, каркасом якої $\epsilon$ інституційна матриця, соціальна система стає міцною.

Інституційна матриця - це сукупність основних політичних, правових, ідеологічних та етичних інститутів, за допомогою яких формується основа суспільства.

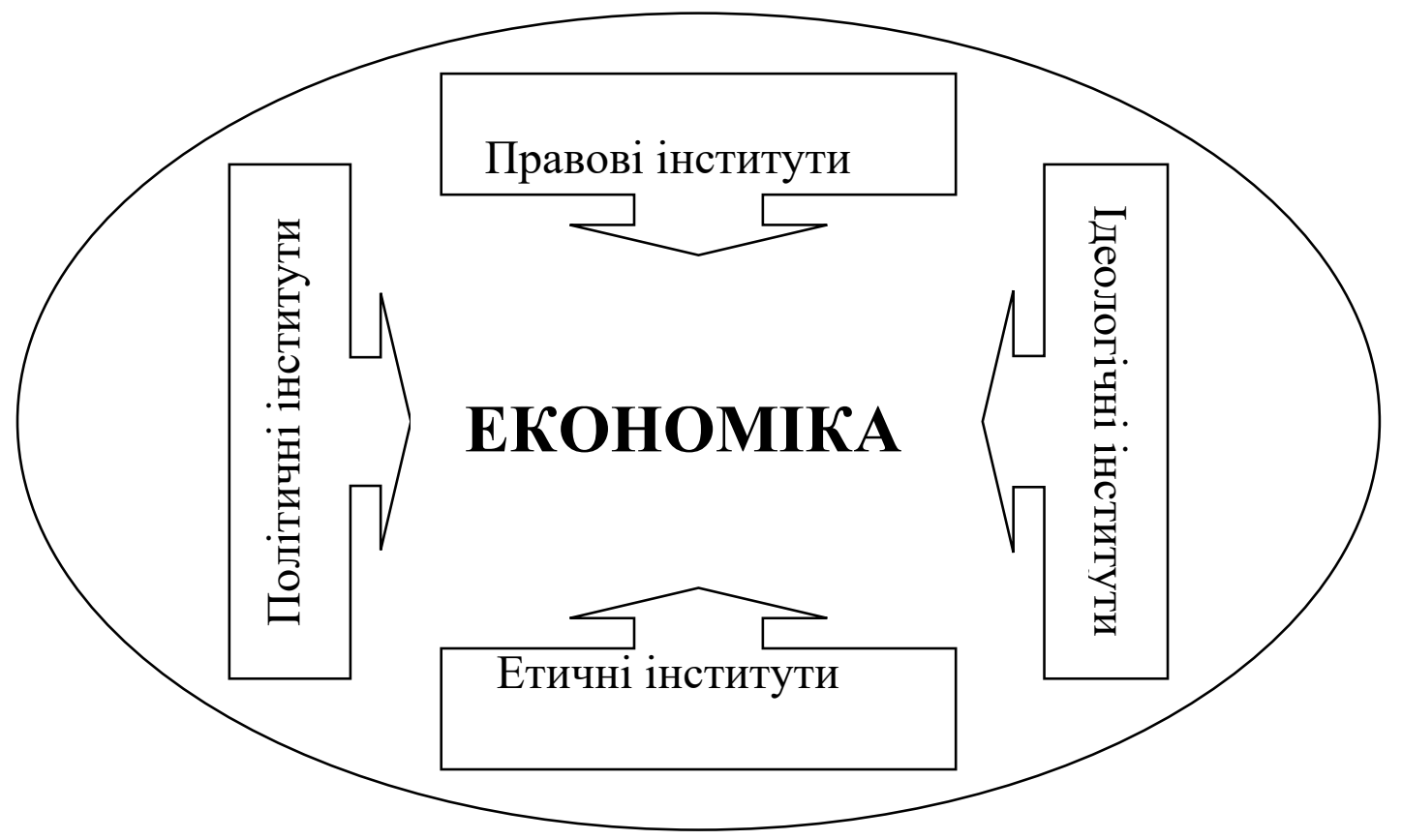

Рис. 6. Принципова схема інституційної матриці суспільної організації Джерело: розроблено автором 
Позаекономічні інститути є стійкими і соціально доцільними інститутами, що фіксуються у звичках, традиціях, стереотипах мислення, неформальних нормах, цінностях, а вже потім і в писаному праві. Саме вони (позаекономічні інститути) визначають особливий характер організації економічного життя держави - тими умовами й обмеженнями, факторами і традиціями, які існували в минулому i продовжують існувати в теперішній час, які формують взаємопов'язані елементи: стереотипи поведінки, які виробляються суспільством на основі звичаїв, традицій і моральних норм, і які визначають більшу частину дій кожного члена певного суспільства, а також відповідний цим групам чи співтовариствам менталітет; соціальні групи суспільства; система виробництва і споживання, освіта і виховання, культура релігія, 3 яких складається структура будь-якого суспільства.

Отже, з позиції динаміки загального позаекономічні інститути (політичні, правові, ідеологічні та етичні) формують каркас інституціональної матриці суспільної організації. Розглянемо класифікацію позаекономічних інститутів:

- правові;

- політичні;

- ідеологічні;

- етичні.

Правові інститути. Правовий інститут - це система взаємопов'язаних норм, які регулюють відносно самостійну сукупність суспільних відносин або їх компоненти [200]. До правових інститутів ми відносимо: примус, легітимність, патерналізм, інститут правопорядку, судові і адміністративні органи, інститут правового виховання.

Джон Роджерс Коммонс у таких працях, як «Розподіл багатства» (1893), «Правові основи капіталізму» (1924), «Інституціональна економіка, іï місце в політичній економії» (1934), «Економічна теорія колективних дій» (1950), за основу аналізу бере позаекономічні інститути - юридичні, правові норми. У цих працях він показав соціально-правовий різновид інституціоналізму. Для його поглядів було характерне твердження про примат права над економікою. Він 
вважав, що саме через юридичну процедуру, через суди регулюються економічні відносини в суспільстві. Юридичні процедури він вважав єдино ефективними для налагодження соціального миру і погашення конфліктів у суспільстві.

У праці «Правові основи капіталізму» Дж. Коммонс зазначив, що суспільство є системою юридичних норм і правових інститутів. Він заперечував існування класів і визнавав наявність лише «професійних груп, які можуть співробітничати шляхом здійснення державою реформ у галузі законодавства і створення уряду, представленого лідерами «колективних інституцій» [136]. Також він будував свої дослідження на дії колективних інститутів: держава, сім’я, виробничі корпорації, профспілки. Суди він розглядає як один з головних факторів економічного розвитку і тлумач права.

Дослідження Дж. Коммонса і Т. Веблена були пов’язані загальною основою теоретичних поглядів, які полягали в тому, що вони обидва віддавали перевагу аналізу позаекономічних факторів суспільного розвитку. Однак, на відміну від Т. Веблена, який пріоритетним уважав психологічні та біологічні фактори, Дж. Коммонс на перше місце виніс аналіз юридично-правових інститутів, ставши лідером соціально-правового інституціоналізму [136]. Держава і право виникає в суспільстві, і вони залежать від рівня його розвитку. Будь-яке суспільство об’єктивно вимагає певного ступеня соціального регулювання та державновладної організації. Недотримуватися цієї закономірності призведе до негативних наслідків для суспільства, які проявляються в неорганізованості чи зарегламентованості соціальних відносин.

I держава, і право тісно пов’язані з політикою, релігією, економікою, філософією та іншими елементами надбудови суспільства, що впливають на рівень його розвитку. Саме удосконалення соціального життя викликає зміну якості регулювання, яка відображається в удосконаленні державно-правових інститутів.

Водночас роль факторів соціально-економічного розвитку для держави та права не слід абсолютизувати, тому що вони в окремі історичні періоди випереджають рівень загального розвитку суспільства i здатні до 
«саморозвитку» та «самовдосконалення».

Політичні інститути. До політичних інститутів належать: держава, соціальні групи як суб'єкти політики, політичні партії, профспілки, громадські організації, соціальні рухи.

Дж. Бьюкенен американський економіст, один із засновників школи нової політичної економії, лауреат Нобелівської премії (1986р.) «за дослідження договірних і конституційних основ теорії ухвалення економічних і політичних рішень», досліджував теорію суспільного вибору та застосування економічних методів до галузей, що традиційно належали до політології. Учасники дослідження Бьюкенена - індивіди, приватні особи, які здатні самостійно приймати такі раціональні рішення, які $є$ вигідними для суспільства. Ця теорія покликана передбачити, як саме поведінка індивідів у певній політичній ролі (як платників податків чи виборців, політиків, суддів чи урядовців) впливає на стан політичного співтовариства.

В економічній теорії Бьюкенен спробував поєднати поведінку індивідів у їх економічній ролі покупців чи урядовців, інвесторів чи виробників 3 результатами, що виявляються на рівні економіки загалом [124]. На його думку, політика є взаємовигідним обміном. Він виокремлює два кардинально відмінні ступені суспільного вибору, а саме: початковий конституційний рівень (до прийняття конституції) і постконституційний рівень.

Початковий конституційний рівень, за Дж. Бьюкененом, передбачає розроблення економічної теорії конституції, а постконституційний -політичних інститутів. За аналогією до гри гравці спочатку обирають правила, за якими будуть грати, а потім на основі обраних правил визначають стратегію. Застосовування аналогії вибору допомагає зрозуміти, як саме правила гри продукують іï вірогідний результат, а конституційні правила продукують результати політики. Отож покращення результатів політики чи результатів процесу прийняття рішень вимагає змін конституції. Визначення, які саме правила гри будуть кращими, відбувається на основі аналізу, в якому руслі і за 
якими правилами будуть грати. Тому конституція - набір правил для проведення політичної гри, а політичні дії - результат гри в рамках конституційних правил.

Політичні інститути (держава, партії, профспілки та ін.) стабілізують домінуючі в суспільстві соціально-класові структури, забезпечують відтворення і стійке збереження ідеологічних цінностей.

Отже, політичні інститути - це держави, партії, профспілки та різного роду громадські організації, що спрямовують свої політичні цілі на встановлення і підтримання певної форми політичної влади. Політичну систему певного суспільства складає сукупність політичних інститутів. Вони забезпечують стійке збереження і відтворення ідеологічних цінностей. Політика досить тісно пов'язана з ідеологією.

У політичній ідеології краще видно як структуру ідеології загалом, так і всіх інших ідеологічних форм, таких як економічна, правова, етична, моральна, естетична, культурна, релігійна та ін. На прикладі політичної ідеології спробуємо показати вплив позаекономічних інститутів на суспільну свідомість (табл. 2).

Таблиия 2

\section{Політичні ідеології та позаекономічні інститути}

\begin{tabular}{|c|c|c|}
\hline Ідеологія & $\begin{array}{c}\text { Позаекономіч } \\
\text { ні інститути }\end{array}$ & Політичні пріоритети \\
\hline 1 & 2 & 3 \\
\hline Комунізм & $\begin{array}{l}\text { - загальна } \\
\text { рівність } \\
\text { - } \\
\text { народовладдя } \\
\text { - свобода } \\
\text { - братерство в } \\
\text { комуні }\end{array}$ & $\begin{array}{l}\text { - пріоритетність інтересів колективу над } \\
\text { інтересами окремої людини } \\
\text { - суспільна власність } \\
\text { - безкласове суспільство } \\
\text { - усуспільненні засобів виробництва } \\
\text { - інтернаціоналізм } \\
\text { - скасування приватної власності на засоби } \\
\text { виробництва (експропріації) } \\
\text { - тотальне державне регулювання економіки } \\
\text { - підкорення людської особистості інтересам } \\
\text { спільноти }\end{array}$ \\
\hline
\end{tabular}


Продовження табл. 2

\begin{tabular}{|c|c|c|}
\hline 1 & 2 & 3 \\
\hline $\begin{array}{l}\text { Соціал- } \\
\text { демократія }\end{array}$ & $\begin{array}{l}\text { - свобода } \\
\text { - рівність } \\
\text { - } \\
\text { справедливіст } \\
\text { ь } \\
\text { - братерство } \\
\text { - солідарність } \\
\text { - колективізм }\end{array}$ & $\begin{array}{l}\text { - віра у верховенство політичної дії, а не } \\
\text { економічної } \\
\text { - рівність усіх форм власності } \\
\text { - ідея демократичної соціальної держави } \\
\text { - націоналізація } \\
\text { - реформізм це бажаний спосіб побудови } \\
\text { соціалізму } \\
\text { - захист прав та інтересів меншин }\end{array}$ \\
\hline Лібералізм & $\begin{array}{l}\text { - свобода } \\
\text { - рівність } \\
\text { - гуманізм } \\
\text { - освіта }\end{array}$ & $\begin{array}{l}\text { - індивідуальні свободи людини є правовим } \\
\text { базисом суспільства та економічного ладу } \\
\text { - відстоює абсолютну цінність людської } \\
\text { особистості } \\
\text { - рівні права і загальна рівність перед законом; } \\
\text { вільну ринкову економіку; } \\
\text { - відстоює мирний шлях реформаторського } \\
\text { здійснення соціальних перетворень } \\
\text { - максимальне послаблення різних форм } \\
\text { примусу щодо особи (державного і суспільного) } \\
\text { - прозорість державної влади } \\
\text { - уряд обраний на чесних виборах } \\
\text { - рівність всіх людей щодо прав особистості } \\
\text { - відкрите суспільство, засноване на плюралізмі } \\
\text { та демократичному управлінні державою }\end{array}$ \\
\hline $\begin{array}{l}\text { Консерватиз } \\
\text { м }\end{array}$ & $\begin{array}{l}\text { - сім’я } \\
\text { - мораль } \\
\text { - традиції } \\
\text { - релігія }\end{array}$ & $\begin{array}{l}\text { - розвиток держави на основі збереження } \\
\text { важливих суспільних інститутів (сім'я, церква) } \\
\text { - прихильність ідеї традиції та спадкоємності в } \\
\text { соціальному та культурному житті } \\
\text { - мінімізація втручання держави в економіку } \\
\text { - відстоювання еволюційно-органічного та } \\
\text { максимально повільного розвитку } \\
\text { - готовність відстоювати національні інтереси } \\
\text { силовими методами } \\
\text { - приватна власність }\end{array}$ \\
\hline
\end{tabular}


Продовження табл.2

\begin{tabular}{|c|c|c|}
\hline 1 & 2 & 3 \\
\hline Націоналізм & $\begin{array}{l}\text { - релігія } \\
\text { - мораль } \\
\text { - } \\
\text { толерантність } \\
\text { - вірність нації } \\
\text { - відданість } \\
\text { нації }\end{array}$ & $\begin{array}{l}\text { - цінність нації як вищої форми суспільної } \\
\text { єдності } \\
\text { - приватна власність та сприяння розвиткові } \\
\text { інших форм власності } \\
\text { - нація головна в державотворчому процесі } \\
\text { - захист прав та інтересів меншин } \\
\text { - толерантні відносини з іншими країнами } \\
\text { - політичну незалежність } \\
\text { - робота на благо власного народу }\end{array}$ \\
\hline $\begin{array}{l}\text { Фашизм } \\
\text { (крайній } \\
\text { націоналізм) }\end{array}$ & $\begin{array}{l}\text { - вірність нації } \\
\text { - } \quad \text { відданість } \\
\text { ідеї } \\
\text { - тоталітаризм }\end{array}$ & $\begin{array}{l}\text { - ідея постійної війни і панування } \\
\text { - приватна власність } \\
\text { - культ сильної особистості } \\
\text { - расизм } \\
\text { - обраність єдиної панівної нацї } \\
\text { - дискримінація стосовно інших «чужорідних» } \\
\text { націй і національних меншин, класів, рас, } \\
\text { партій, профспілок, індивідів } \\
\text { - зіставляє інститутам і цінностям народовладдя } \\
\text { так званий «новий порядок» та жорсткі способи } \\
\text { його утвердження } \\
\text { - виселення емігрантів } \\
\text { - незаперечний авторитет «вождя» } \\
\text { - силова експансія у зовнішній політиці } \\
\text { - заперечення демократії та відкритості влади } \\
\text { - пріоритет військово-промислового комплексу }\end{array}$ \\
\hline
\end{tabular}

\section{Джерело: розроблено автором}

До основних політико-правових інститутів належать: держава, політичні партії і суспільні рухи, судові й адміністративні органи, інститути правотворчості, об'єднання, правового виховання, інститути правопорядку і соціального контролю, прав людини, вирішення правових конфліктів та ін. Ці політико-правові інститути здійснюють певний вид соціальної діяльності по управлінню і регулюванню суспільними стосунками.

Держава $є$ найважливішим політико-правовим інститутом сучасного 
суспільства, а також основним джерелом законів і інших правових актів, що призначено для організації життя суспільства.

Ідеологічні інститути. Ідеологія - система поглядів, ідей, переконань, цінностей та установок, що виражають інтереси різних соціальних груп, класів, товариств, в яких усвідомлюються і оцінюються відносини людей до дійсності і одне до одного, соціальні проблеми і конфлікти, а також містяться цілі (програми) соціальної діяльності, спрямованої на закріплення або зміну існуючих суспільних відносин [133]. Ідеологія об’єднує різноманітні погляди в єдине ціле, має колосальний вплив на життєдіяльність суспільства, шляхом прискорення або гальмування його розвитку.

До ідеологічних інститутів належать: мораль, ментальність, справедливість, рівність, звички, традиції та культура.

Неокласична школа, кейнсіанство, монетаризм, марксизм і інституціоналізм - усі ці напрями економічної думки функціонують як ідеологія, виступаючи одночасно як вираження систем цінностей і як пізнавальні системи.

Важливою функцією організованих ідеологій є узгодження економічних інтересів, досягнення задовільного рівня однорідності уявлень про відносини між людьми в тому чи тому суспільстві як у позитивному, так і в нормативному плані. Це означає не тільки схожість уявлень про те, якою «повинна бути» економічна політика, а й однорідність у розумінні взаємозв'язків між елементами економічної системи, що у свою чергу передбачає існування відповідного ідеології економічного механізму [125, с. 94].

О. О. Бєляєв зазначає, що використання ідеології як засобу координації інститутів веде до подвійного результату. Наприклад, як початковий поштовх вона може бути ефективно використана для зміни поведінки людей у потрібному напрямку, який не обов'язково збігається 3 умовами максимізації їхнього добробуту в короткостроковому аспекті. Але тією ж мірою, якою ідеологія стає перепоною поведінці людей, пов’язаною з максимізацією їхнього добробуту, вона сама поступово починає руйнуватися, перетворюючись на набір пустих фраз, кліше, догм [125, с. 94]. Ідеологія дає відчуття справедливості, але в 
жодному разі вона не є принципом справедливості.

Етичні інститути. На сучасному етапі суспільного розвитку все більш гостро постає проблема етичної культури та моралі, посилення їх ціннісного аспекту. Етична культура допомагає усвідомити цінності людського життя, визначити якісні показники свого буття, особливо в умовах суспільноекономічної кризи.

До етичних інститутів віднесемо такі: виховання, освіта, релігія, довіра, етична культура, етична мораль, етична поведінка, вірність, відданість, самовладдя.

Інституціональні дослідження базуються на вченні про людину (екзистенціалізм), її поведінку, мораль тощо та пов'язані з проблемами етики в економіці. Етична поведінка - це продукт таких інститутів, як релігія, система освіти, виховання [125, с. 90].

Керуючись вище сказаним, зобразимо структуру позаекономічних інститутів (правових, політичних, ідеологічних, етичних) на рівні інституційної матриці суспільної організації (рис. 7).

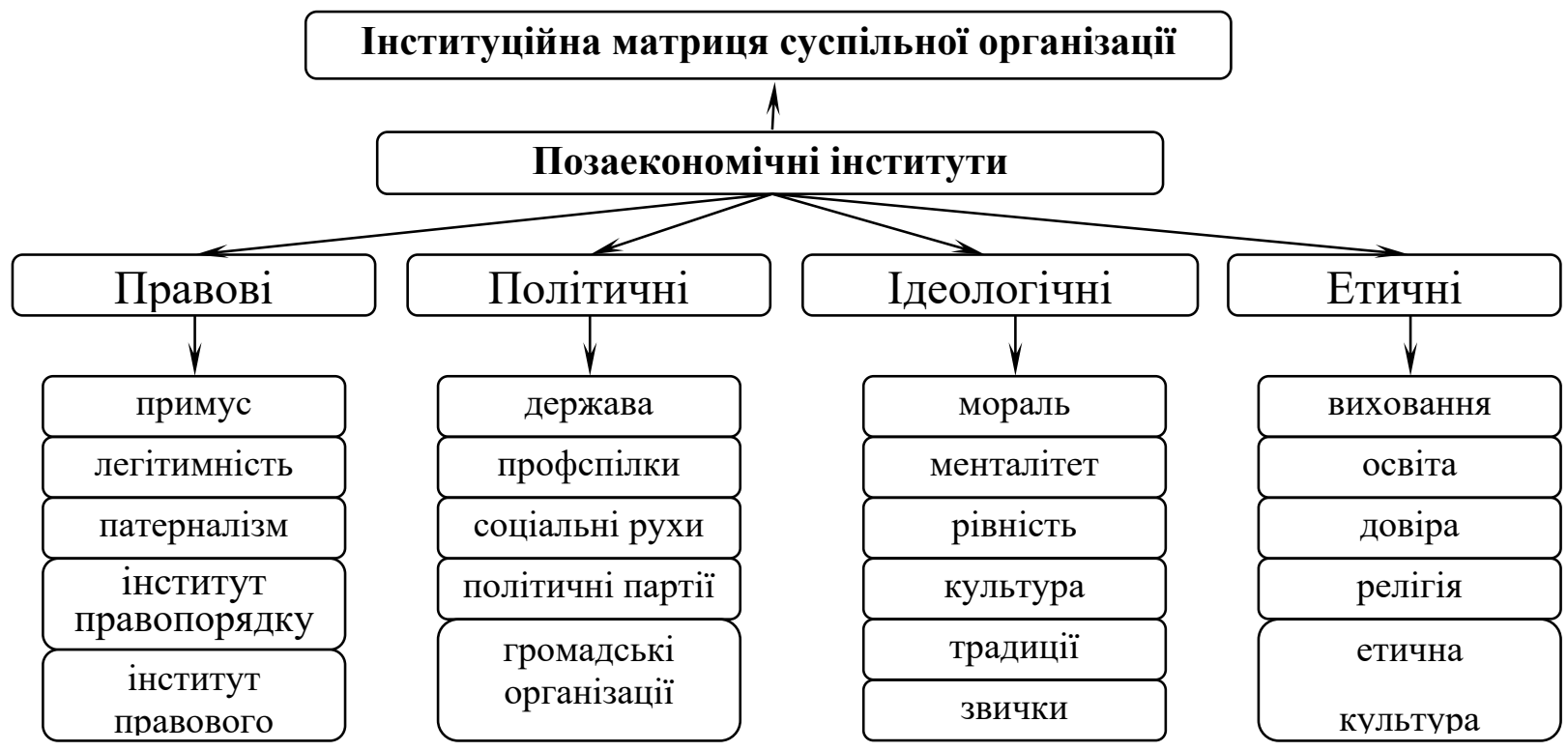

Рис. 7. Структура позаекономічних інститутів на рівні інституційної матриці Джерело: розроблено автором

Якісний і структурний вплив позаекономічних інститутів може проявлятися 
як через систему стимулів, так і через систему обмежень.

Система обмежень. У нашому дослідженні системою виступають: організації на мікрорівні, регіони на мезорівні, держава на макрорівні. Обмеженнями є позаекономічні інститути, які не тільки можуть погіршити керованість системи, але й покращити їі.

Система обмежень скорочує строки досягнення бажаного результату. Якщо необхідний результат не досягнутий за короткий термін, необхідно переходити від системи обмежень до системи стимулів. Невдача системи обмежень може відбутися, коли досить мала кількість учасників цієї мережі впевнені в іiі позитивному результаті.

У нашому випадку позаекономічні інститути можуть виступати як обмеженнями, так і стимулами. Уся система обмежень пов'язана між собою причинно-наслідковими в'язками. Досліджувана складова системи позаекономічних інститутів може бути некерованою як і всі інші складові системи. Проте позаекономічні інститути складаються 3 таких елементів: правових, політичних, ідеологічних та етичних, котрі у свою чергу поділяються на ще менші структурні елементи - більш керовані через свій розмір.

Для стабільного соціально-економічного розвитку через відтворення соціального капіталу необхідно правильно підібрати потрібні обмеження, які покращать ефективність усієї соціально-економічної системи.

Обмеження повинні встановлюватися на найвищому щаблі в кожному 3 досліджуваних рівнів, оскільки встановлення обмежень на нижчих щаблях може призвести до бездієвості обмежень через досягнення компромісів між учасниками цієї мережі. У нашому випадку кожна зі сторін, досягаючи компромісу, відмовляється від чогось, а це є неправильно, оскільки затягує час для досягнення поставлених цілей. Встановлення обмежень на найвищому рівні убезпечує виникнення ситуації, коли потрібен компроміс. Визначення i встановлення оптимального обмеження, яке буде працювати постійно й ефективно, дає можливість досягнути стабільність у соціально-економічному 
розвитку через мінімізацію трансакційних витрат, спростити взаємовідносини і підвищити щільність взаємодій між економічними агентами.

Позаекономічні інститути в ролі обмежень вимагають керованості з боку системи і забезпечують досягнення необхідного результату без додаткових вкладень чи ресурсів.

Методологічно проблему врахування соціально-культурних, моральноетичних, духовних факторів у системі економічних відносин розв’язують у рамках інституціональної теорії. Значення неекономічних факторів в економічному механізмі має бути визнано досить важливим, до позаекономічних чинників ми відносимо менталітет народу, звички та стереотипи мислення, довіру, освіту, релігію, культуру.

Економіка країни безпосередньо залежить не тільки від економічних показників, але й від неекономічних (моральних) показників, таких як чесність, старанність, працьовитість, довіра. Наприклад, ефективне функціонування держави, а особливо фінансової сфери, неможливе без активного залучення заощаджень найширших верств населення в обіг спеціалізованих фінансових установ, у тому числі й недержавних пенсійних фондів, страхових організацій [209], створення однаково доступних умов для підприємств до джерел фінансування. Це можливо лише в разі, якщо випереджаючими темпами порівняно з кількісними характеристиками зростання фінансового ринку будуть розвиватися відносини фінансово-економічної довіри, якими пронизані практично всі фінансові процеси: кредитування, інвестування, страхування життя та інше [211].

Позаекономічні інститути - це формальні та неформальні правила і норми поведінки, що безпосередньо не пов'язані з організацією економічної діяльності та забезпечують цілісність процесу відтворення соціального капіталу. Вони опосередковують цей зв'язок через передбачуваність і мотивацію поведінки економічних суб’єктів, мінімізацію трансакційних витрат, доступ до необхідної інформації, ресурсів і благ, спрощення взаємовідносин і взаємодії між економічними агентами. Це у свою чергу дає можливість зекономити на 
масштабах діяльності.

Подальший розвиток досліджень позаекономічних інститутів допоможе пошуку шляхів стабільного відтворення соціального капіталу.

На сьогоднішній день усе більш актуальною стає проблема соціальних відносин між людьми, що виступають не лише складовими соціальної структури суспільства, а також їх ресурсом. Саме теорія соціального капіталу концентрує свою увагу на таких поняттях, як відносини та зв'язки.

Дослідження сутності категорії «соціального капіталу» є досить складним процесом, зміст цієї категорії більшість економістів, соціологів, політологів розкривали 3 точки зору своєї галузі знань, хоча i тісно пов'язували іiі 3 економічним розвитком регіону чи країни загалом. Людина $\epsilon$ основою гуманістичної ідеї, яку містить у собі концепція соціального капіталу.

На відміну від фізичного, людський капітал не є уречевленим - він виступає у знаннях. Людський капітал, як і соціальний, збільшується у процесі використання. Відмінність соціального капіталу від людського полягає в тому, що він втілюється в соціальних взаємовідносинах акторів, тому не є власністю конкретного суб' єкта. Схожість соціального капіталу з іншими видами капіталів полягає в тому, що для його збереження та відтворення необхідні інвестиції.

«Капітальна» складова соціального капіталу проявляється в його здатності знижувати трансакційні витрати, невизначеність i ризик, підвищувати ефективність використання специфічних активів та ін. Якщо фізичний капітал втілений в обладнанні та будівлях, то соціальний капітал є нематеріальною субстанцією. Соціальний капітал втілений у відносинах, існуючих між членами сім'ї, групи, суспільства, нерозривно пов'язаний з ними і тому не може продаватися або передаватися в користування або володіння. «Соціальна» складова соціального капіталу виявляється в тому, що його носієм $є$ сім'я, група, суспільство, а накопичення і використання відбувається у відносинах між друзями, колегами по роботі, просто незнайомими людьми». До «капітальної» складової соціального капіталу можна віднести: 
- обмеженість (нерівний доступ до соціальних мереж, норм і цінностей; радіус довіри);

- накопичення (примноження соціального капіталу відбувається в результаті розширення та щільності соціальних мереж при збільшенні рівня довіри);

- ліквідність (можливість обміну його на різні блага). Він представляє собою взаємовідносини і знаходиться у структурі зв'язку між акторами (економічними агентами). При цьому включеність окремих індивідів у мережі і характеристика цих мереж (розмір, щільність, сила і інтенсивність мережевих зв'язків) впливає на розмір соціального капіталу;

- можливість конвертації в інші форми капіталу: існування соціального капіталу досить тісно пов'язане з іншими формами капіталу. Соціальний капітал можливо реалізувати через його конвертацію у процесі виробництва в інші значущі форми капіталу. Він виражається у відносинах, тоді як інші форми капітулу - в суб'єктах і об'єктах. Актори, що використовують соціальний капітал, можуть отримувати прямий доступ до економічних ресурсів, можуть бути причетні до інститутів, які розподіляють привілеї, або можуть примножити свій культурний капітал;

- для відтворення необхідні певні інвестиції (вкладення економічних, культурних, символічних ресурсів задля збільшення рівня довіри, примноження соціальних контактів);

- здатність створювати додаткову вартість, у деяких випадках можна досягти збільшення показників результативності в тих мережах, де панує довіра та згуртованість.

Капітальне благо: соціальні мережі, довіра, норми та цінності є складовими соціального капіталу на одиничному рівні і водночас на загальному рівні вони $€$ позаекономічними інститутами, що мають властивості до нагромадження, розширення та інвестування в економічний кругообіг.

Соціальний капітал - це елемент сталого економічного розвитку суспільства, чинник розвитку національної економіки, умова формування і 
функціонування громадянського суспільства. Капітал - це певне багатство, що дозволяє досягати бажаного результату.

Розбіжності у визначеннях терміна «соціальний капітал» пояснюється тим, що вчені, які займалися дослідженням цієї проблеми, працювали в різних теоретичних направленнях. До того ж структурні елементи соціального капіталу - соціальні мережі, норми та довіра - існують у різних економічних, політичних, правових, культурологічних умовах.

Незважаючи на різне трактування терміна «соціальний капітал», майже всі вчені схиляються до думки, що ключова роль цього капіталу полягає в тому, що він сприяє зміцненню довіри між учасниками, а також є одним із факторів ефективного розвитку економіки, організації, соціальної групи та ін. [93, с. 29, с. 59, c. 75, c.].

Структурна основа соціального капіталу утворює мережі соціальних зв'язків, на основі яких формується інституційна основа цього капіталу, крім того, включає відповідні норми та цінності, довіру. Соціальний капітал допомагає акторам краще знати можливі дії один одного, знижує ризики і трансакційні витрати. Він дає можливість людині, групі, суспільству простіше та швидше залагодити виниклі проблеми чи питання, а довіра, взаємозв'язок, норми взаємної відповідальності допоможуть у формуванні та збереженні необхідної поведінки в певному колективі.

Соціальний капітал - це чинник, який забезпечує через функції неформальної регуляції економіки, позаекономічні конкурентні переваги економічним суб'єктам. Неформальна регуляція проявляється за допомогою громадської думки, міжособистісних стосунків.

Щоб збільшити обсяг соціального капіталу, треба мати певний соціальний ресурс (зв’язки, контакти) та бути включеним у соціальну мережу, в основі якої відносини побудовані на довірі та дотриманні норм.

До соціального капіталу ми відносимо соціальні мережі, норми та цінності, довіру. За їх допомогою можна досліджувати відносини держави і громадських 
організацій, стан довіри в суспільстві, вплив на економічний розвиток, умови життя та інше.

Уперше в 1916 році в роботі «Сільські общинні школи» Л. Дж. Ханіфан застосував термін «соціальний капітал» у дискусіях про сільські школи для опису громадських осередків сільської освіти та вагомих обставин, які впливають на повсякденне життя кожного та для визначення «тих матеріальних субстанцій, які мають особливе значення у повсякденному бутті людей». У результаті цього зроблено висновок про необхідність розвитку братських почуттів, взаєморозуміння та взаємодії; виховання волі, взаємної симпатії, вміння налагоджувати соціальні взаємини і комунікацію серед людей. Цей термін також використаний у праці «Смерть і життя великих американських міст» Джейн Джейкобс, де вона пояснила, що густа соціальна мережа, яка існувала в старіших кварталах змішаного міського типу, сприяє громадській безпеці, складаючи форму соціального капіталу.

Термін «соціальний капітал» використовували у 1970-х роках економіст Глен Лаурі, а також соціолог Іван Лайт для аналізу проблеми економічного розвитку центральної частини міста. Вони з’ясували, що афроамериканцям бракувало зв’ язків довіри і соціальної прив’ язки у власній громаді, на відміну від середовища азійських американців та інших етнічних груп, що і пояснило поганий розвиток малого бізнесу серед темношкірого населення.

3 часом термін «соціальний капітал» набув ширшого застосування в науковому обігу. Класики світової соціології М. Вебер, Т. Веблен, Е. Дюркгейм, Ф. Теніс першими пояснили трансформацію індивідуальної довіри людини в «упредметнену довіру» окремого співтовариства.

Американський економіст і соціолог Торстейн Веблен ще у 1899 p. використовував концепцію соціального капіталу при характеристиці «праздного класу». Клас, який використовував цей капітал, вийшов із суспільства для того, щоб жити за рахунок праці інших [102].

Соціальний капітал формують норми, що мають охоплювати такі, цінності: правда (чесність), взаємозв’язок і дотримання зобов’язань. Не дивно, що ці 
норми значною мірою накладаються на ті протестантські цінності, які Макс Вебер у книзі «Протестантська етика та дух капіталізму» визначив критичними для розвитку західної цивілізації [101]. У праці розглянуто питання зв'язку між віросповіданням і соціальними розшаруваннями, проаналізовано комплекс психологічних і культурних факторів, що сприяють утвердженню ринкових відносин в економіці.

Водночас у працях М. Вебера й Е. Дюркгейма закладені основи дослідження концепції соціального капіталу, де довіра, яка перестає бути індивідуальною якістю, характеризує особистість та може розповсюдитися повністю на соціальну групу чи суспільство і $є$ головним компонентом соціального капіталу.

Професор соціології Каліфорнійського університету Джонатан Тернер убачає в концепції соціального капіталу один з новітніх підходів у соціології, що має багато спільного, по-перше, зі структурним функціоналізмом, по-друге, 3 економічним мисленням. Він вважає соціальний капітал властивістю соціуму, яку визначають взаємозв'язки, котрі формуються між людьми в усіх сферах їх життєдіяльності; пропонує вивчати проблеми сучасного суспільства через аналіз взаємозв'язків між його структурними елементами 3 точки зору людських взаємин [156]. Отже, поняття «соціальний капітал» виступає головним елементом науково-дослідницького інструментарію аналізу соціальних явищ. Особливо це стосується вивчення економічної сфери, де соціальний капітал $є$ означенням сил, що підвищують потенціал економічного розвитку суспільства через стимулювання і створення моделей людських взаємин як головних складників загальної моделі соціальної організації.

Лише у другій половині XX століття завдяки видатним працям П. Бурдьє, Дж. Коулман, Р. Патнема, Ф. Фукуями та інших започатковано та розвинуто категорію «соціального капіталу», що ввійшла в науковий обіг, пов’язуючи її 3 підвищенням економічного розвитку та економічної діяльності. Вони вважають важливими ресурсами соціальної взаємодії економічних агентів неформальні інституційні практики та немонетарну мотивацію. 
Американський дослідник Джеймс Коулман дає визначення соціальному капіталу як потенціалу взаємної довіри та взаємодопомоги, що націлено та раціонально формується в міжособистісних взаєминах (зобов'язання та очікування, соціальні норми). Він інтерпретує соціальний капітал як ресурс, спосіб організації економічного й соціального життя населення або, точніше, як «колективне благо» (Public Good); використовує поняття соціального капіталу для аналізу відносин усередині групи людей, об’єднаних спільними цінностями, нормами, світоглядом, а також взаємними зобов'язаннями.

Дж. Коулман оригінально здійснив системний аналіз процесу формування соціального капіталу й акцентував увагу на ролі соціального капіталу у створенні людського капіталу, зокрема в досягненні індивідом певного освітнього рівня. Індивід вносить у практику соціального життя різні нові норми соціального життя і нові форми взаємних зобов'язань, що мають забезпечити відносини довіри, щоб створити певні моральні рамки тієї чи іншої групи. Він зазначає, що «соціальний капітал виникає з таких змін у відносинах людей, які полегшують їх взаємодію ... Так само як фізичний або людський капітал, соціальний капітал вносить свій внесок у результати виробничої діяльності. Соціальний капітал - це ресурси соціальних відносин, їх мережі, які полегшують дії індивідів завдяки формуванню взаємної довіри, визначенню взаємних зобов’язань і очікувань, формулюванню і встановленню соціальних норм, освіти асоціацій... Тому спільнота людей, що володіє надійною репутацією і великим потенціалом довіри, може досягти значно більших успіхів, ніж аналогічна група осіб, що не володіє цими якостями». Дж. Коулман основною нормою, що представляє собою одну 3 форм соціального капіталу сучасних суспільств, виділяє норму колективізму (готовність докласти своїх зусиль для досягнення загального блага); це сприяє виникненню поняття «соціальна мережа» як системи взаємодії індивідів, які спільно виконують певну роботу, оскільки мають спільні групові або організаційні цілі.

Важливо, що одним з механізмів породження соціального капіталу він вважав привілейований доступ до інформації (а такий доступ, з одного боку, $\epsilon$ 
наслідком володіння соціальним капіталом на попередньому етапі суспільної діяльності, а з другого - первинним джерелом поширення доступу до інформації на наступному етапі) [89]. Він доводить, що «соціальний капітал залежить від властивостей соціальної структури, характеру відкритості соціальних мереж, тривалості соціальних відносин та множинності зв' язків (множинний зв’ язок між двома людьми означає, що вони пов'язані кількома видами діяльності або ролями)» $[149$, с. 166].

Дж. Коулман убачав, що первинний соціальний капітал - це той, який створює стійкі відносини, а довіра, яка виникла в їх результаті, у свою чергу, самоутворює взаємність, і як наслідок таких взаємних відносин - генерація довіри і на макрорівні, у результаті чого формуються спільні цінності. На його думку, соціальний капітал - це форма капіталу, що пов’язана зі встановленням зв’язків з іншими господарюючими агентами, а також це сукупність відносин, що спонукають до дії. Ці відносини пов’язані з очікуванням того, що інші агенти будуть виконувати свої обов’язки без застосування санкцій $[148$, с. 122]. Ця одночасна концентрація зобов'язань та очікувань веде до росту довіри між економічними агентами, а отже, і соціального капіталу.

Дж. Коулман указує, що соціальний капітал продуктивний, він сприяє досягненню певних цілей, отримання яких при його відсутності неможливе [148, c. 124], також «соціальний капітал - це потенціал взаємної довіри i взаємодопомоги, ... формований у міжособистісному просторі. ... Соціальний капітал утворює норми і мережі, обслуговуючі колективні дії». Тому соціальний капітал є необхідним доповненням для ефективного функціонування людського та фізичного капіталу.

Соціальний капітал обумовлений тим, що кожний економічний суб’єкт інтегрований у систему соціальних відносин, а саме: співробітництва, взаємної довіри та взаємодопомоги, взаємодії, капіталу спілкування, що утворюються в просторі міжособистісних економічних відносин.

Говорячи про сутність соціального капіталу, можна прослідкувати, що використана Дж. Коулманом модель економічної людини не дозволяє розкрити 
(виявити) у процесі акумуляції соціального капіталу роль таких позаекономічних чинників, як релігія, культура, звички та традиції, відсутність визначення ускладнює класифікацію явищ і процесів, що належать до сфери функціонування соціального капіталу.

На відміну від Дж. Коулмана, який вважав зв’язки важливими як для еліти, так і для малозабезпечених осіб та колективів, П. Бурдьє в роботі «Форми капіталу» акцентує увагу на тому, що соціальний капітал «являє собою сукупність реальних чи потенційних ресурсів, пов’язаних $з$ володінням стійкою мережею більш чи менш інституалізованих відносин взаємного знайомства та визнання» [98, с. 67]. Автор стверджував, що привілейовані особи підтримують свій стан завдяки власним зв’язкам серед таких же привілейованих осіб. На його думку, соціальний капітал - це ніщо інше, як просто мережа групових зв’язків. А на думку багатьох соціологів, рівень соціального капіталу можливо визначити через інституційну характеристику мереж і ступінь включеності в ті чи інші мережі.

Важливий внесок у розвиток поняття соціального капіталу зробила теорія французького соціолога i філософа П. Бурдьє, який виокремив соціальний простір від фізичного і диференціював капітал на соціальний (нематеріальний), або позаекономічний, і матеріальний, або економічний, банківський, фінансовий та інші. П. Бурдьє встановив взаємозв'язок між соціальним, людським, культурним і фізичним капіталами, а вже на основі цієї взаємодії визначив соціальний капітал як диференціюючий i конструюючий чинник соціальної поведінки. При цьому П. Бурдьє заявляє, що результати володіння соціальним капіталом зводяться до економічного капіталу, проте їх не можна розглядати як альтернативні форми. Соціальний капітал $є$ сукупністю явних і потенційних ресурсів, які передбачають наявність системи інституційних відносин взаємного визнання, він має власну динаміку і характеризується порівняно з економічним капіталом більшою невизначеністю і меншою прозорістю.

Після праці «Сільські общинні школи» Л. Дж. Ханіфан П. Бурдьє звернувся до питання забезпечення елітою своєї переваги. Ця перевага чітко виокремлює 
соціальний простір від фізичного і зосереджується на диференціації капіталу, а саме: на економічному (матеріальна безпека), на раціональному або соціальному (тісні взаємовідносини), на культурному капіталі (якість мови), якими володіє кожний. Ці «капітали» є родовими ознаками, на основі яких еліти, на відміну від звичайних людей, забезпечують свою перевагу.

Досліджуючи соціальний капітал, французький науковець не відриває його від соціального простору, наголошуючи, що соціальний капітал - це один 3 різновидів капіталу, які визначають статус людини в соціальному просторі, а також що це своєрідний ресурс, одержаний індивідом завдяки членству в асоціаціях, який дає йому реальні можливості і переваги, i, нарешті, що це влада, яка гарантує певні шанси на успіх у конкретних ситуаціях [142]. 3 цього випливає, що соціальний капітал має два аспекти: перший - соціальні відносини, що дають індивідам доступ до ресурсів, якими володіють інші індивіди; другий - кількість і якість ресурсів, якими індивід може оволодіти. П. Бурдьє доходить висновку, що володіння соціальним капіталом спричинює володіння економічним капіталом, тобто відносини нематеріального характеру (довіра, авторитет, рейтинг) можуть давати матеріальний ефект (престижну посаду, вищу заробітну плату, додаткові джерела поліпшення життєвого комфорту) [89]. У нашому дослідженні цей матеріальний ефект ми будемо розглядати у формі соціальної ренти.

За П. Бурдьє, об’єм соціального капіталу є функцією розміру мережі й об’ єму капіталу (економічного, культурного та соціального), яким користуються індивіди, об’єднані в певну соціальну мережу.

П. Бурдьє, досліджуючи «соціальний капітал», виявив, що він визначається відносинами реципрокності «reciprocity» - очікуванням взаємного обміну, що є можливим без довіри. Він визначав соціальний капітал як «сукупність актуальних або потенційних ресурсів, які пов’язані з наявністю міцних мереж зв’язків, більш-менш інституціолізованих відносинами взаємного знайомства i визнання» [98, с. 65]; за автором, це особистий внесок кожного члена панівного 
класу, групи або соціальної мережі з метою збереження своїх провідних позицій у суспільстві.

На думку П. Бурдьє, соціальний капітал, на відміну від інших форм, найбільше пов’язаний з іншими формами капіталу. Він ідентифікує такі основні форми капіталу: економічний, культурний, соціальний і символічний. Якщо використовувати соціальний капітал, можливо отримати прямий доступ до економічних ресурсів, але водночас щоб отримати соціальний капітал, необхідні певні вкладення економічних, культурних і символічних ресурсів.

Він стверджує, що результати володіння соціальним і культурним капіталом зводяться до економічного капіталу, разом з тим вони не можуть бути розглянуті як його альтернативні форми. Соціальний капітал «складається 3 соціальних зобов’язань (зв’язків), які можуть бути конвертовані, при певних умовах, в економічний капітал і можуть бути інституціоналізовані у формі титулу або знатності».

Сутність соціального капіталу, за П. Бурдьє, полягає в тому, що «вибудувати це поняття означає створити спосіб вивчення логіки, згідно якої цей особливий вид капіталу накопичується, передається, відтворюється; створити спосіб розуміння того, як він трансформується в економічний капітал і, навпаки, ціною яких зусиль економічний капітал може конвертуватися в соціальний, створити спосіб усвідомлення функцій таких інститутів, як клуби, або просто сім’ї - основного місця акумуляції та передачі цього виду капіталу». Оскільки саме панівна група визначає мову, цінності, судження, моделі успіху і невдач ... окремі види капіталу, як козирі в грі, є владою, яка визначає шанси на виграш в даному полі...» [97].

Під впливом наукових робіт Дж. Коулмана про соціальний капітал професор Гарвардського університету Роберт Патнем зосередив свою увагу на значенні громадських співтовариств та асоціацій, а головний його внесок полягає в тому, що володіння соціальним капіталом відіграє велику роль у становленні добробуту людей. 
Роберт Патнем визначає соціальний капітал через «характеристики соціального життя - мережі, норми і довіру, - що спонукають учасників до більш ефективної спільної дії для досягнення спільних цілей». Виміряє соціальний капітал за допомогою індивідуальних індикаторів (інтенсивність і сила контактів, членство в об'єднаннях, електоральна активність, відчуття безпеки, довіра).

У працях Р. Патнема використана трифакторна модель соціального капіталу (тріада):

- норми взаємності;

- довіра;

- соціальні мережі.

Соціальні мережі Р. Патнем визначає як міжособистісне спілкування, або громадянське, зобов'язання. Соціальні мережі (знайомства, зв'язки) надають людям широкий вибір можливостей, що веде до покращення матеріального становища (підвищення по кар'єрній драбині). Вони є основою повсякдення.

У книзі Р. Патнема i його колег Р. Леонарді i Р. Нанетті «Творення демократії. Традиції громадянської активності в сучасній Італії» (1993) розкрито вплив соціально-культурних факторів та історичної традиції на політичний розвиток Півночі і Півдня Італії [167]. Роберт Патнем звернув увагу на те, що північні регіони, де люди більш соціально активні (за показниками явки на виборах, участі в асоціаціях, зацікавленості в місцевих справах), краще скористалися переданими повноваженнями, у «пасивних» південних, навпаки, якість управління впала. У центрі його уваги - осередок соціального життя цивільна громада 3 культурно визначеними рисами поведінки її членів, у якій «ціннісні ставлення і зразки практики утворюють взаємно підтримуючий еквілібрум». Єдність культури і структури, що складається в межах цивільних громад, характеризує поняття соціального капіталу. Воно включає в себе норми взаємності (толерантність, довіра) та мережі громадянського залучення (участь людей у різного роду спілках та об’єднаннях). Взаємно підсилюючи один одного, 
ці два аспекти соціального капіталу сприяють підвищенню дієздатності людей, сприяють солідаризації, кооперації та взаємодопомозі.

Р. Патнем довів, що найважливішим досягненням формування соціального капіталу в Італії (як і будь-якій іншій країні) є висока довіра громадян одне до одного. Індивіди можуть співпрацювати ефективніше, якщо вони довіряють одне одному задля досягнення спільних цілей і реалізації спільних інтересів. I навпаки, відчужені люди, які не мають довіри одне до одного, можуть опинитися в когорті невдах за межами громадянського суспільства. У цій книзі італійські соціологи спочатку описують ті негативні явища в економічній сфері, що відбуваються через недовіру і нездатність співпрацювати заради досягнення загального блага $[167$, с. 204]. Для функціонування демократичних інститутів люди схильні добровільно підкорятися правовим нормам і створювати сприятливе соціальне середовище.

Дослідження, зроблені Р. Патнемом в Італії, показали, що мережа місцевих добровільних організацій створює соціальний капітал (навички, знання, громадянські цінності), необхідний для консолідації демократії. «Люди, зацікавлені в демократії, іiі консолідації й ефективності, повинні передусім сприяти формуванню громадянського суспільства. Ми підтримуємо тих, хто виступає за трансформацію місцевих структур і реформи на місцевому рівні 3 метою створення соціального капіталу, а не лише за загальнодержавні ініціативи, оскільки саме так можна домогтися ефективного функціонування демократії» $[167$, c. 24].

Деякі дослідники виділяють не три, а чотири елементи соціального капіталу, а саме: соціальні мережі, загальні норми, цінності та довіра. Ми будемо розглядати норми та цінності як один із трьох структурних компонентів соціального капіталу.

На думку Френсіса Фукуями, «соціальний капітал - це загальноприйняті норми і цінності, які практикуються певною групою людей і дозволяють їм співпрацювати; це - певний потенціал суспільства або його частини, що виникає як результат наявності довіри між його членами. Соціальний капітал $\epsilon$ 
неформальною практикою розуму». Він доводить, що соціальний капітал необхідний для успіху кожної країни у сфері глобального економічного i політичного устрою. У праці «Соціальний капітал і світова економіка» дослідник зазначає: «Здорова капіталістична економіка опирається передусім на досить високий рівень соціального капіталу громадянського суспільства, що сприяє підвищенню самоорганізації в бізнесі, корпораціях і подібних структурах... Саме тенденція до самоорганізації життєво необхідна для ефективної діяльності демократичних політичних інститутів». На думку автора, кожне суспільство має певний соціальний капітал, проте кожен «власник» соціального капіталу має різний «радіус довіри».

Соціальний капітал як і фізичний, на думку Ф. Фукуями, інколи може бути використаний з деструктивною метою чи застаріти, не завжди він $є$ позитивним. Він не тільки може застаріти, але й може бути використаний для виробництва бойових рушниць, вульгарних розваг і будь-якого іншого негативу. Кожне суспільство має закони, що забороняють виробництво фізичним чи соціальним капіталом найгірших соціальних «нечистот». Отже, соціальний капітал використовується не в менш корисних із соціальної точки зору цілях, ніж продукція фізичного капіталу.

Ф. Фукуяма наголошує на тому, що «закон, договір, економічна доцільність $€$ необхідним, але аж ніяк не достатнім базисом стабільності і добробуту в постіндустріальний період - вони повинні спиратися на такі речі, як взаємодія, моральні зобов'язання, відповідальність перед суспільством і довіра». Соціальний капітал, за твердженням Ф. Фукуями, - це певний набір неформальних цінностей чи норм, яких дотримуються члени групи, що дає їм змогу співпрацювати один з одним.

Ф. Фукуяма прирівняв довіру i соціальний капітал, хоча до елементів соціального капіталу він відносив і довіру, і сформовані у процесі комунікації та взаємодії загальні системи норм, цілей і цінностей.

Аналіз досліджень і публікацій указує, що українські науковці (В. Сікора, А. Колодій, А. Багнюк, А. Бова, Є. Гугнін, В. Чепак, О. Кірєєва, М. Лесечко, 
В. Паніотто, Н. Харченко, А. Чемерис, Ю. Савко, О. Сидорчук, В. Степаненко, Ю. Зайцев та ін.) приділяють також велику увагу дослідженню та вивченню проблеми соціального капіталу в громадянському суспільстві.

На думку українського економіста М. Туган-Барановського, автора теорії соціально-економічних криз, конкуренція і кооперація є двома основними взаємодоповнюючими процесами ринкової економіки і сьогодні тісно пов'язані 3 теорією розвитку соціального капіталу суспільства. У праці «Соціальні основи кооперації» (1916р.) він виклав основи теорії соціального капіталу на основі конкуренції і кооперації, які, на його думку, є взаємодоповнюючими процесами в економіці.

В Україні тільки започатковується впровадження в науковий обіг категорії «соціальний капітал». Уперше на науковій конференції «Громадянське суспільство і соціальні перетворення в Україні» професор Антоніна Колодій у доповіді «Соціальний капітал: зміст та евристична цінність концепції» порушила питання про евристичну цінність цієї категорії [145]. Згідно з концепцією, А. Колодій розглядає взаємозв'язок соціального капіталу і громадянського суспільства. Останне вона асоціює з цінностями довіри, розсудливості та толерантності, формується громадянська позиція громадянська i добропорядність, саме тому його учасники з довірою ставляться до своїх колег по діяльності, до інших людей і громадських інститутів, визнають право інших громадян на власну думку і захист. Соціальний капітал є основним продуктом, який забезпечує вплив громадянського суспільства на інші сфери суспільного життя, ознакою його зрілості та ефективності громадянського суспільства.

А. Колодій виділяє наступні компоненти, з яких складається концепція соціального капіталу:

• мережа горизонтальних зв'язків між рівними і вільними індивідами;

- норми взаємності й довіри;

• навички колективних дій;

• почуття участі у громадських справах, обов'язки й відповідальності перед іншими людьми, тобто «громадянськість» у іï неполітичних проявах (civicness) 
[146]. На нашу думку, з першими двома компонентами, з яких, за А. Колодій, складається соціальний капітал, ми погоджуємося, проте останні два компоненти є зайвими, оскільки вони виникають у межах перших двох компонентів. «Навички колективних дій» виникають у межах певної соціальної групи (мережі) на основі встановлених у цій мережі норм. «Почуття участі у громадських справах, обов'язки і відповідальності перед іншими людьми» $є$ бажанням індивіда належати до тієї чи іншої мережі, в якій панують комфортні умови для існування на основі взаємності та довірчих відносин.

Український науковець Веніамін Сікора у своїх працях проаналізував економічну сутність соціального капіталу. Проведені дослідження у країнах 3 перехідною економікою засвідчили, що високий рівень довіри й участь населення у громадських організаціях сприяє в довготривалій перспективі економічному зростанню завдяки полегшенню передачі інформації, зниженню затрат на примус і контроль. Він зазначає: «Соціальний капітал стає головним напрямом економічного мислення в сфері економічного розвитку і фактично утверджується як нова парадигма. Соціальний капітал фактично складає 78 \% у сукупному багатстві розвинених ринкових економік. Соціальний капітал виробляє те, без чого не може існувати ринкова економіка - довіру між людьми» [210]. Взаємовідносини в мережі, побудовані на довірі, $\epsilon$ стійкішими та довготривалішими. Такі мережі швидше досягають поставлених цілей, оскільки скорочується час на перевірку та пошук інформації (учасники мережі довіряють один одному), знижуються трансакційні витрати і практично відсутній примус (відносини в групі побудовані на принципі взаємної допомоги).

В. Степаненко провів аналіз концепції соціального капіталу в умовах посткомуністичного суспільства і показав його зв'язок 3 формуванням громадянського суспільства в Україні. М. Лесечко та О. Сидорчук аналізують соціальний капітал 3 позицій державного управління та відносин держави 3 носіями соціального капіталу [155]. Е. Гугнін і В. Чепак визначають соціальний капітал як одну з форм, що, будучи багатофункціональною, сприяє задоволенню інтересів індивіда і водночас обслуговує суспільні та групові інтереси [112]. 
А. Багнюк визначає соціальний капітал як будь-яку іншу форму капіталу, яка передбачає обмін, що відбувається певними порціями (дозами), де порція отриманого має перевищувати порцію вкладеного, у результаті чого з'являється логічна необхідність у застосуванні такого поняття, як «суспільна квантифікація». Соціальний капітал - це «капітал соціального спілкування, капітал людських взаємин через обмін квантами істини, добра, краси, справедливості, закону, віри, правди» [89, с. 44].

Ю. Савко виділяє такі три структурних компоненти соціального капіталу:

- соціальні відносини (індивіди можуть мати доступ до ресурсів їхніх партнерів по спілкуванню);

- обсяг і якість доступних ресурсів партнера по спілкуванню;

• відносини взаємності обміну [208].

А. Бова вказав, що в Україні відбувається тенденція до зменшення соціального капіталу, і зазначив, що особливістю цієї тенденції є зниження довіри до органів державної влади та падіння громадської активності на тлі збільшення довіри до сім'ї, родичів, колег, церкви і, відповідно, активізацію діяльності саме в родинній та церковній сферах [93]. Автор виділив такі складові соціального капіталу: довіру до формальних і неформальних зв'язків; членство у громадських та політичних організаціях; освіта; вільний доступ до інформації; норми, традиції, цінності.

Д. Д. Попов зазначає, що соціальний капітал представляє сукупність двох форм - структурної та інституційної. Структурний соціальний капітал полегшує отримання інформації, сприяє колективним діям і спільному прийняттю рішень шляхом розподілу ролей, формування соціальних зв'язків та інших соціальних структур, пов'язаних із правилами. Це об’єктивна форма соціального капіталу. До інституційного соціального капіталу належать норми, цінності, взаємна довіра. Це суб'єктивна форма соціального капіталу [202].

Г. В. Рожков розглядає такі (рис. 8) форми соціального капіталу. Перші дві форми соціального капіталу взаємодоповнюючі і можуть формуватися один 3 одного. У табл. 3 розкрита характеристика форм соціального капіталу. 


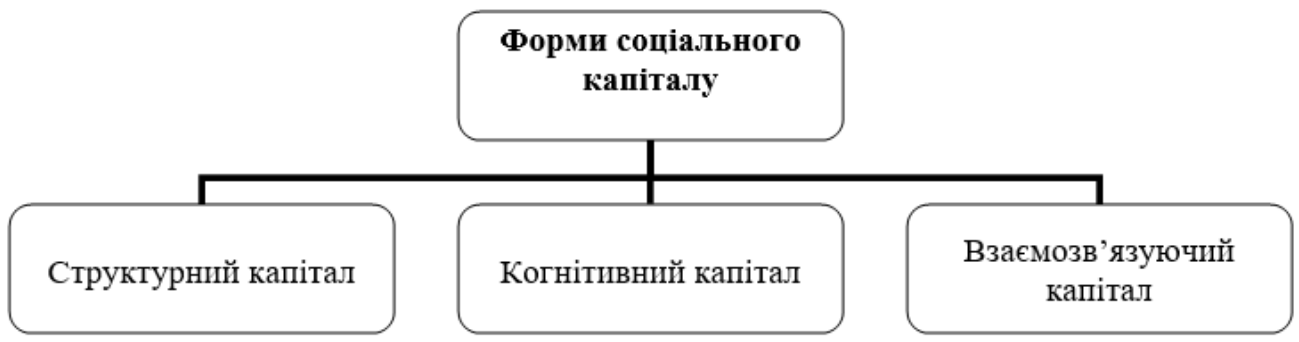

Рис. 8. Форми соціального капіталу

Джерело: розроблено автором на основі [207]

Таблиия 3

Форми соціального капіталу та їх характеристика

\begin{tabular}{|c|c|c|}
\hline Структурний капітал & Когнітивний капітал & $\begin{array}{c}\text { Взаємозв'язуючий } \\
\text { капітал }\end{array}$ \\
\hline $\begin{array}{c}\text { соціальні мережі, їх } \\
\text { форма і відповідні } \\
\text { організації }\end{array}$ & $\begin{array}{c}\text { загальні коди, мова та } \\
\text { способи розповіді }\end{array}$ & $\begin{array}{c}\text { довіра, норми, } \\
\text { зобов'язання та } \\
\text { ідентифікація }\end{array}$ \\
\hline \multicolumn{3}{|c|}{ характеристика } \\
\hline $\begin{array}{c}\text { Він пов’язаний з рядом } \\
\text { соціальних факторів - } \\
\text { соціальними ролями, } \\
\text { процедурами, } \\
\text { прецедентами і } \\
\text { мережами, які } \\
\text { полегшують корисне } \\
\text { для обох сторін } \\
\text { співпрацю }\end{array}$ & $\begin{array}{c}\text { Він проявляється в } \\
\text { посилених культурою } \\
\text { або ідеологією ідеях, } \\
\text { специфічних нормах, } \\
\text { цінностях, поглядах, } \\
\text { переконаннях, сприяють } \\
\text { співпраці }\end{array}$ & $\begin{array}{c}\text { Він виявляється у } \\
\text { вербальному прояві } \\
\text { елементів соціального } \\
\text { капіталу, які не мають } \\
\text { матеріального } \\
\text { висловлювання }\end{array}$ \\
\hline
\end{tabular}

Джерело: розроблено автором на основі [207]

Загалом науковці виділяють ще й такі форми соціального капіталу:

1. Структурна форма соціального капіталу розкривається акторами (індивідами) через соціальні мережі. Чим щільніший зв'язок, чим більший розмір мережі, тим міцніший соціальний капітал. Мережі формуються на мікрорівні в 
сім'ї; на мезорівні - серед колег або друзів, в організації; на макрорівні взаємозв'язки на рівні суспільства та держави.

2. Інституційна форма розкривається через сукупність норм і цінностей, які регулюють взаємодії між різними групами. Норми - це зразки правильної поведінки або взаємодії.

3. Культурна форма соціального капіталу розкривається через механізм довіри. Сім'я, колектив, організація, держава, суспільство буде розвиватися ефективніше, якщо взаємозв'язки учасників побудовані на довірі.

Користуючись вище сказаним, на наш погляд, соціальний капітал має такі 3 структурні елементи: соціальні мережі, норми та цінності (як єдине ціле) і довіру (рис. 9). Далі охарактеризуємо і грунтовно розглянемо кожен з них.

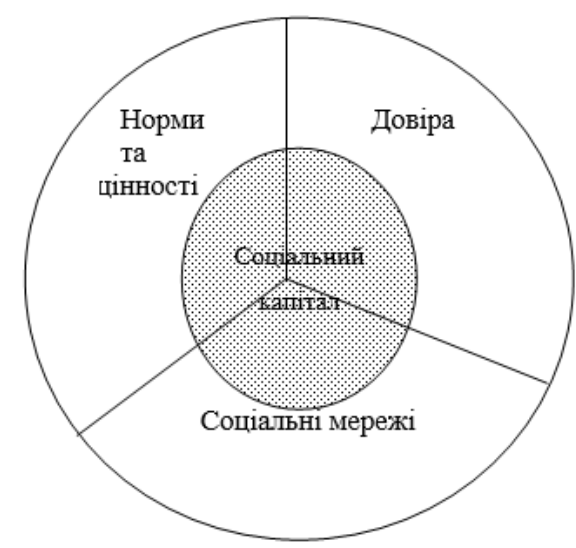

Рис. 9. Структура (тріада) соціального капіталу

\section{Джерело: розроблено автором}

Соціальні мережі. Маючи мережу соціальних зв'язків, економічні агенти «належать» до певної соціальної групи і користуються певними привілеями, які може надати та чи та соціальна група. Ці привілеї полягають у взаємодопомозі (надавши якусь послугу, актор (агент) буде чекати на допомогу у відповідь).

Проте «...нерідко (а навіть - найчастіше) в мережі соціальних зв’язків підприємців безпосередньо залучаються державні структури і окремі державні чиновники, що істотно знижує і якість державного управління, і підриває 
можливості для подальшого зміцнення соціального капіталу першого типу» [207]. Л. Н. Федотов вважає, що основоположна ідея концепції соціального капіталу полягає в тому, що соціальні мережі створюють основу для соціальних зв’язків, оскільки в них люди можуть кооперуватися одне 3 одним для досягнення взаємної допомоги, успіхів і вигод. Елементами соціального капіталу виступають: 1) соціальні зв’ язки і шляхи, якими вони створюються, 2) довіра, що забезпечує дії членів суспільства як єдиного цілого; 3) нормативи і правила, які зміцнюють довіру, 4) інститути, що забезпечують функціонування суспільства. Автор вважає, що не кожна соціальна мережа є соціальним капіталом, якщо в цій мережі учасники не дотримуються позитивних цілей цієї групи.

У роботі «Слабкі місця структури в порівнянні з завершеною мережею соціального капіталу» (2000р.) американський дослідник Р. Барт зазначив, що «соціальний капітал є не простою сутністю, а варіацією різних сутностей 3 такими спільними характеристиками: 1) усі сутності складаються 3 деякого аспекту соціальної структури та 2) сприяють здійсненню деяких вчинків індивідів, які належать до цієї структури». У праці пояснено мережеву структуру соціального капіталу. Мережа, на думку автора, - це система функціонування соціального капіталу як інституту соціальної реальності, а соціальний капітал $є$ закритою мережею, у якій люди можуть взаємодіяти на рівні неформальних взаємовідносин.

Соціальний капітал має структурну основу, що утворює мережі соціальних зв’язків, за допомогою яких можна скоротити трансакційні витрати і зекономити ресурси, сформувати імідж та ін. На основі соціальних мереж формується інституційна основа соціального капіталу (належність до певної групи, суспільства).

«Коли існує норма, причому ефективна, вона створює міцну, хоча часом і тендітну форму соціального капіталу. Наприклад, ефективні норми, які приймаються для боротьби із злочинністю, дозволяють людям, навіть літнім, вільно ходити вночі по місту чи залишати свій будинок, не побоюючись за своє майно» [207]. Норми суспільної поведінки передаються від одного покоління до 
іншого у процесі соціалізації, що здебільшого відбувається за звичаєм, а не через якусь причину.

Ф. Фукуяма визначає, що «сукупність неформальних правил або норм, поділених членами групи, дозволяє їм взаємодіяти один з одним. Норми, що створюють соціальний капітал, навпаки, повинні включати в себе такі чесноти, як правдивість, зобов'язання, взаємність». За допомогою норм цінності впроваджуються в життя, вони допомагають індивіду обрати ту чи іншу модель поведінки. Спільні цінності в групі, організації, суспільстві згуртовують членів мережі за поглядами, діями, переконаннями, що веде до прискореного та ефективного досягнення цією мережею накреслених цілей.

Першим, хто дав визначення поняття «цінності», був фахівець у галузі аксіології К. Клакхон: «Це усвідомлене або неусвідомлене, характерне для індивіда або для групи індивідів уявлення про бажане, котре визначає вибір цілей (індивідуальних або групових) з урахуванням можливих засобів і способів дії». I далі: «Без цінностей життя суспільства було б неможливим, функціонування соціальної системи не могло б зберегти спрямованість на досягнення групових цілей; індивіди не могли б отримати від інших те, що їм потрібно в плані особистих та емоціональних відносин; вони також не відчували б у собі необхідну міру порядку та спільності цілей». Дотримання індивідом певних норм і цінностей, що переходять 3 покоління в покоління, спонукає до виникнення соціального капіталу.

Довіра. Довіра у відносинах між акторами допомагає створенню міцних ділових зв'язків або об’єднань. Усе частіше в науковій літературі прослідковується той факт, що соціальні мережі та довіра відіграють значну роль в економічному розвитку.

Р. Патнем вважав довіру складовою соціального капіталу, що сприяє успішному розвитку економіки і демократичних інститутів. Участь у різного роду асоціаціях, спілках тощо сприяє акумуляції в суспільстві соціального капіталу і зумовлює зростання довіри в міжперсональних стосунках. Він зазначав, що зміцненню довіри допомагає «соціальна довіра, норми 
реципрокності, мережі соціальних зобов'язань і успішна кооперація зміцнюють один одного. Ефективні спільні інститути вимагають навичок міжособистісного спілкування і довіри, тоді як розвитку цих навичок і встановленню довіри також сприяє організована співпраця». Реципрокність - це рух предмета обміну на основі взаємності між суб'єктами.

Дж. Коулман дотримувався позиції першочерговості довіри, вважаючи, що довіра сприяє накопиченню соціального капіталу. А взаємини міжперсональної довіри формують «систему довіри» - «це поширення взаємин довіри на макрорівень, де вони виступають у формі нормативних розпоряджень». Він акцентує увагу на тому, що актор здійснює раціональні інвестиції у власний соціальний капітал, тобто актор взаємодіє в групі за встановленими правилами, і винагородою стає довіра, яка дає змогу приєднатися до всіх інших видів ресурсів мереж.

Дж. Коулман наводить яскравий приклад довірчих відносин між економічними акторами на основі ринку оптової торгівлі алмазами в Нью-Йорку. Контроль за цим ринкам здійснюють декілька єврейських сімей, які без будьяких формальних контрактів передають один одному для дослідження досить цінні алмази, при цьому не побоюючись, що компаньйон їх замінить або привласнить. А основне в тому, що експерти-оцінювачі не тільки працюють разом, а й живуть один біля одного, відвідують одні і ті ж синагоги. Як наслідок тісних соціальних зв'язків, ці люди можуть успішно займатися високоприбутковим бізнесом, основаним на повній довірі до партнерів.

Міцні відносини створюються за допомогою соціального капіталу, у результаті цих відносин виникає довіра. Нині на кожному кроці ми можемо побачити соціальний капітал, пов'язаний 3 довірою - це там, де успішно працюють такі трудові колективи, у яких зібрані не просто гарні фахівці, а люди, які одне одному довіряють.

Дещо іншої позиції притримуються Ф. Фукуяма, П. Бурдьє. На їхню думку, основними складовими соціального базису є довіра, спонтанні асоціації та зобов'язання. Френсіс Фукуяма зауважує, що «довіра - це виникаючі у членів 
суспільства очікування того, що інші його члени будуть поводитися більш-менш передбачувано, чесно і з увагою до потреб оточуючих, у згоді з деякими громадськими нормами».

Довіра - це культурно-виробничі відносини, в які вступають учасники економіки задля реалізації цілей та інтересів [147, с. 4]. Особливим видом довіри $\epsilon$ політична, вона більшою мірою показує емоційне ставлення населення до владних інститутів (політичних лідерів, політичних партій) і влади загалом, а також їх готовність брати участь у різних формах політичної, економічної, соціальної діяльності.

О. Демків пропонує таку модель трактування феномену довіри відповідно до рівнів соціального капіталу:

- на мікрорівні (рівні індивідуального соціального капіталу) міжособистісна довіра має вирішальне значення;

- на мезорівні (рівні групового соціального капіталу в межах ширшої групи) важливою є як міжособистісна довіра, так і категоріальна й групова довіра (згідно із класифікацією П. Штомпки);

- на макрорівні (найвищому рівні групового соціального капіталу всього суспільства) найважливіше значення має так звана «узагальнена довіра», довіра до політичних інститутів, системна довіра (до політичного режиму) та інституційна довіра [116, с. 106].

Прослідковується взаємозв’язок і взаємовплив рівнів соціального капіталу до всіх типів довіри.

Соціальні мережі, норми та цінності, довіра одночасно $є$ складовими соціального капіталу 3 позиції особливого та виступають структурними елементами позаекономічних інститутів з позиції одиничного.

Особливість інституційної матриці полягає в темпах відтворення соціального капіталу (на рівні одиничного через мережу позаекономічних зв’язків, які побудовані на довірі, закріплені за допомогою норм і цінностей). Соціальні мережі, довіра, норми та цінності соціальної поведінки - це внутрішні позаекономічні інституціональні ознаки соціального капіталу (рис. 0). 


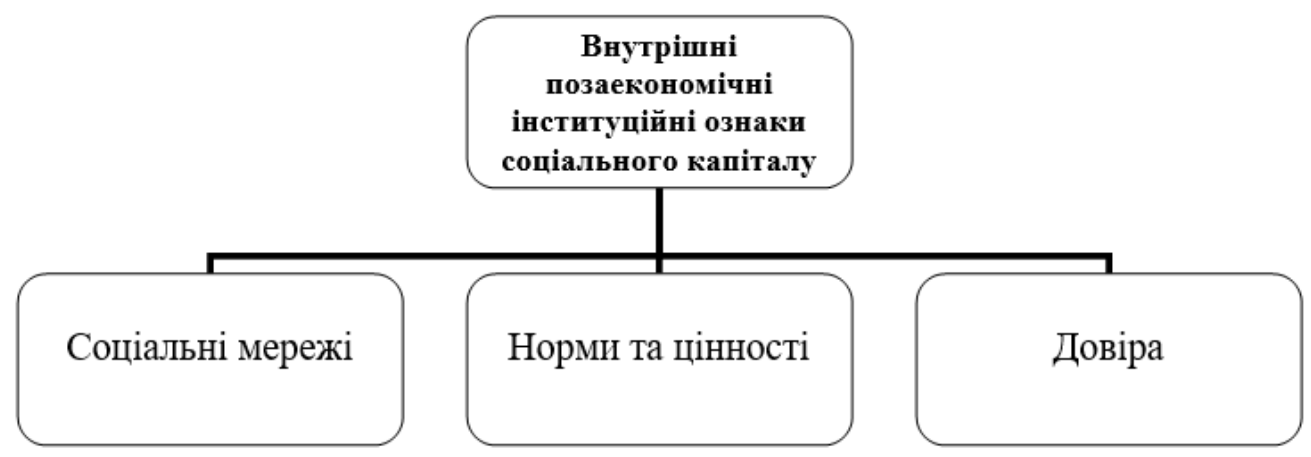

Рис. 10. Внутрішні позаекономічні інституційні ознаки соціального капіталу

\section{Джерело: розроблено автором}

Внутрішні позаекономічні інституційні ознаки соціального капіталу надають стійкість інститутам i забезпечують ефективний процес їх самовідтворення.

Дослідження соціально-економічної системи не оминули проблеми визначення їх основоположних принципів і закономірностей. Дотепер є не 3'ясованим питання, чи є соціум системою, яка може самоуправляти за допомогою позаекономічних інститутів, чи, згідно з доктриною лібералізму, економічна система визначає шлях суспільства.

Нині у світі у зв'язку з пошуком нових джерел підвищення благоустрою соціуму відбувається переоцінка соціально-економічний цінностей. Високий рівень інтеграційних зв'язків на всіх рівнях, а також глобалізація спонукає більше звертати увагу з позиції загального на такі позаекономічні інститути, як соціальні мережі, норми та цінності, довіра.

У науковій літературі виділяють ряд економічних функцій соціального капіталу. Значення соціального капіталу в системі сучасних економічних відносин полягає в тому, що соціальний капітал впливає на мотивацію i поведінку діяльності економічних агентів, виконує функції сприяння 
(підтримки) і регулювання обміну; забезпечує доступ до благ і ресурсів; мінімізує трансакційні витрати, тощо.

Соціально-мотиваційна компонента, яка характеризується рівнем суспільної свідомості і відповідальності, соціальною зрілістю, економічними інтересами і потребами населення, є важливим системоутворюючим елементом трудового потенціалу [210].

Економічну функцію соціального капіталу Ф. Фукуяма пояснює тим, що він «повинен зменшувати операційні витрати, пов'язані 3 формальними механізмами координації»: створення бюрократичної ієрархії та певних правил, контракти тощо, робить висновок, що «координація, заснована на неформальних нормах, стає важливою частиною сучасної економічної діяльності». Прогрес спонукає до змін не тільки у сфері технологій, але і в соціальній сфері, що спричиняє пошук нових способів суспільної регуляції. При такій постановці проблеми першочергового значення набувають фактори соціального капіталу та довіри, які є обов'язковими елементами, присутніми у відносинах усіх суб'єктів економічного простору.

С. А. Сисоєв на основі ідеї Дж. Коулмана [148] виділив основні причини виникнення соціального капіталу:

- «генерування» соціального капіталу у відносинах з оточенням (надаючи ту чи іншу послугу, моральну підтримку, людина очікує, що в разі необхідності може розраховувати на відповідну підтримку з боку іншої, тобто отримати економічний або соціальний ефект від своєї взаємодії з іншими людьми. Умови, що сприяють виникненню соціального капіталу: персоніфіковані відносини між агентами (люди поступово дізнаються про характер і звички один одного, це полегшує взаємодію, підвищує ступінь довіри), повторюваність взаємодії (економічний агент знає, що контрагент може «погасити» свої зобов'язання в майбутньому), наявність інституційних рамок (норми, неформальний механізм примусу), які гарантують виконання зобов'язань;

- індивід дотримується культурних і релігійних норм. Такі норми «розчинені» в суспільстві. Вони відтворюються і передаються з покоління в 
покоління через виховання в сім'ї та систему освіти. Величина соціального капіталу, яка може бути актуалізована в суспільстві, залежить від кількості людей, які поділяють такі норми;

- альтруїзм, безкорисливі вчинки також здатні приводити до виникнення соціального капіталу. Прикладом може бути створення батьківського комітету в школі, завданням якого $є$ допомога адміністрації у вирішенні проблем, пов'язаних з навчальним процесом;

- як побічний продукт взаємодії агентів. Наприклад, повторення взаємодії працівників у рамках фірми сприяє встановленню персоніфікованих відносин між ними. Спільні інтереси, взаємна симпатія між товаришами по службі трансформують відносини - вони з формальних перетворюються на дружні. Це скорочує трансакційні витрати при обміні інформацією всередині фірми, підвищує їі стійкість.

Тривалий час жити ізольовано не може ніхто, тому соціальний капітал $\epsilon$ продуктом діяльності різних груп індивідів (сім'ї, родини, громади, профспілки, фірми), а його функція - забезпечити ресурсами кожного члена групи (асоціації) [142]. Кожен економічний актор приймає рішення, виходячи із взаємозв'язків зі своїми партнерами. Ці взаємовідносини сприяють обміну інформацією, допомагають у вирішенні конфліктних ситуацій, вибудовують репутацію, таким чином включаючи у процес ринкової взаємодії позаекономічні фактори.

Соціальний капітал можна визначити як свідоме використання суб'єктом соціальних мереж, що за допомогою встановлених норм і загальноприйнятих цінностей і довіри стають можливістю для досягнення поставлених цілей.

Позаекономічні інститути утворюють обмеження (рамки) для діяльності людини, вони виступають нормами поведінки, що виникли із взаємодії індивідів і регулюють різні сфери людської діяльності та організують їх у систему ролей і статусів, що утворюють соціально-економічну систему. Інституціональна діяльність здійснюється людьми в групах чи асоціаціях, де існує поділ на ролі і статуси відповідно до потреб конкретної соціальної групи чи суспільства 
загалом. Таким чином, позаекономічні інститути, як і економічні, підтримують порядок у суспільстві.

Позаекономічні інститути властиві всім економічним системам, але масштаби їх дії залежать від існуючих соціокультурних норм і державної ідеології, вони ефективно виконують покладені на них функції: координаційну, регулятивну, обмежувальну, інформаційну, закріплювальну, виховну та ін. (рис. 11).

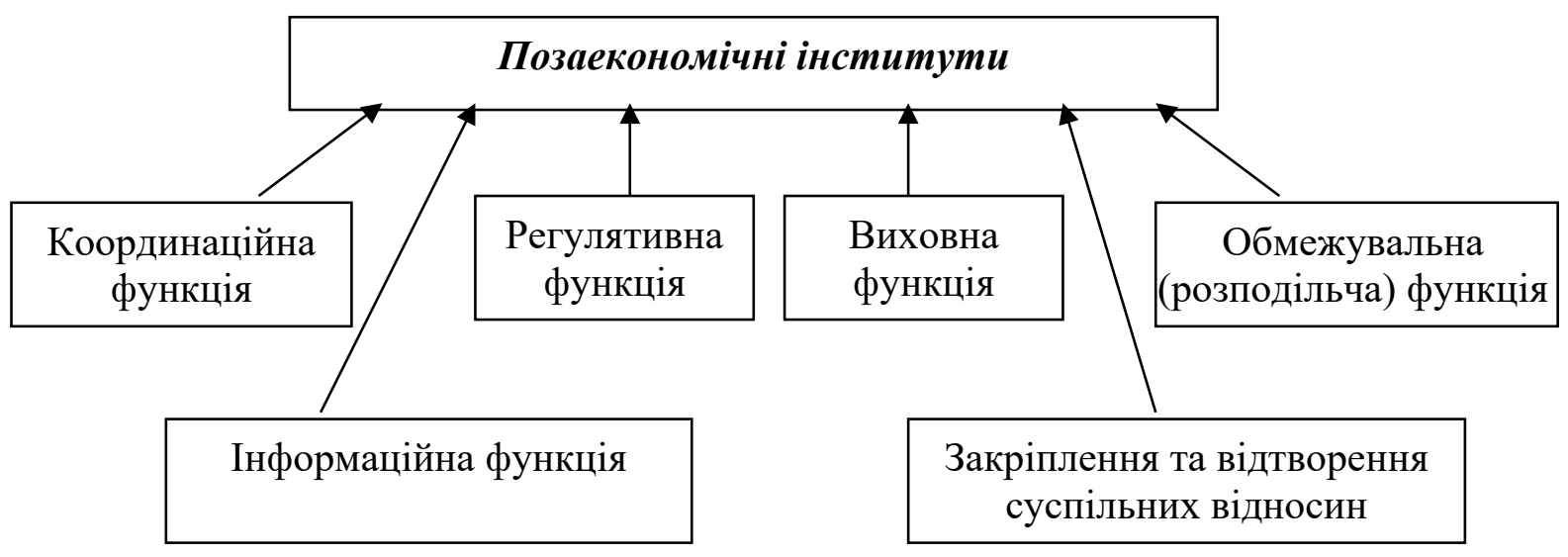

Рис. 11. Основні функції позаекономічних інститутів

Джерело: розроблено автором

Функції позаекономічних інститутів та їх роль у структуротворенні соціального капіталу:

1. Координаційна функція. Координує поведінку людей (економічних агентів). У результаті цієї даної функції виникає координаційний ефект інститутів, що реалізується шляхом зниження рівня невизначеності середовища, у якому діють індивіди (економічні агенти); дає можливість задовольнити потреби та інтереси.

2. Регулятивна функція. Регулювання відносин між людьми таким чином, щоб вони не завдавали одне одному збитків або в разі заподіяння збитків могли чимось компенсувати їх. Ця функція полягає в регулюванні за допомогою моральних норм, правил поведінки, стереотипів мислення дій людини в межах соціально-економічних відносин, тобто відбувається виконання бажаних дій i усунення небажаної поведінки. 
Ця функція регулює діяльність членів мережі в межах соціальних відносин i проявляється у здатності позаекономічних інститутів до організації, координації, узгодження, кооперації соціально-економічної взаємодії, керування та управління нею.

3. Обмежувальна (розподільча) функція. Впливає на розподіл ресурсів між економічними агентами.

4. Інформаційна функція. Передбачає організацію процесу передачі інформації, а це дає можливість зекономити зусилля на збір та обробку інформації, чим полегшує роботу у виборі альтернатив, оскільки чим більшою кількістю інформації володіє людина, тим більший у неї вибір альтернатив, результатом чого є менша вірогідність поступити невдало.

Позаекономічні інститути допомагають скоротити трансакційні витрати (витрати на пошук, збір та обробку інформації, витрати на укладання контрактів, ведення переговорів). Забезпечує інтеграцію бажань і дій членів соціальної мережі.

5. Закріплення та відтворення суспільних відносин. Позаекономічні інститути містять систему правил і норм поведінки, що допомагають зробити передбачуваною поведінку людини. Соціальний контроль забезпечує порядок i межі, у яких має протікати поведінка кожного члена інституту. Регулює в рамках соціальних відносин діяльність членів мережі, суспільства.

6. Виховна функція. Забезпечує соціалізацію підростаючого покоління та стабільність суспільного життя.

Роль позаекономічних інститутів у структуротворенні соціального капіталу полягає в тому, що вони на рівні одиничного визначають мережу позаекономічних зв'язків суб'єктів соціальної взаємодії, обумовлених сумісністю цінностей і відносин довіри, закріплених у формальних чи неформальних нормах.

Соціальний капітал допомагає зміцненню суспільної стабільності та сталому розвитку завдяки взаємодії між членами групи, їхній довірі один до одного, дотриманню певних норм та цінностей, що панують у цій соціальній 
групі. Економічний актор є невід’ємною частиною соціальних відносин (належність до мережі у процесі міжособистісних економічних відносин), побудованих на основі дотримання встановлених норм і цінностей, взаємодії та взаємодопомоги, довіри між іiі членами. Міцність і тривалість цих відносин залежить від складових соціального капіталу: соціальних мереж, норм i цінностей, довіри. Свідоме використання економічним актором соціального капіталу дає можливість зекономити на витратах і швидше досягти поставлених цілей та отримати економічну вигоду (соціальну ренту) від використання внутрішніх позаекономічних інституційних ознак соціального капіталу (соціальних мереж, норм та цінностей і довіри).

Використання теорії соціального капіталу в економічних дослідженнях має на меті розв’язання ряду методологічних проблем, основна з яких - вимірювання та аналіз його складових. За останній час проблемою вимірювання соціального капіталу займалося багато науковців, однак через певні обставини вони були змушені щоразу повертатися до цього питання.

Вимірювання соціального капіталу - це досить складний процес, оскільки соціальний капітал і його складові є нематеріальними ресурсами. Насамперед розглянемо рівні накопичення соціального капіталу, а вже потім - як відбувається його вимірювання відповідно до цих рівнів.

На процес акумулювання соціального капіталу здійснюють вплив персоніфіковані відносини, якщо люди довго знають одне одного, то, відповідно, вони мають і більше інформації про кожного. У результаті цього ущільнюються зв’язки між індивідами в певному колі спілкування і відбувається зростання довіри, що позитивно впливає на швидкість накопичення соціального капіталу.

У науковій літературі є опис соціального капіталу та його кіл взаємодії на мікро-, мезо- та макрорівнях суспільства, однак підходи до визначення його сутності на цих рівнях сильно відрізняються. Так, на мікрорівні одні автори розглядають соціальний капітал як ресурс окремого агента (актора), а інші - як ресурс невеликої групи осіб чи домогосподарства. У результаті відсутності 
єдиної думки з цього приводу необхідно детальніше розглянути характеристику та градацію рівнів соціального капіталу.

Розглядаючи розширене та багатоступеневе дослідження рівнів соціального капіталу, яке, на думку Н. І. Ларіонової [152], необхідно розглядати на таких рівнях: нано-, міні-, мікро-, мезо-, макро- та мегарівні для кращого розуміння процесу накопичення соціального капіталу.

Нанорівень. На цьому рівні соціальний капітал розглядається як індивідуальний, його розмір визначається як внутрішніми затратами, так i зовнішніми інвестиціями. Внутрішні затрати - знання, навички, харизма. Зовнішні інвестиції - витрати на вкорінення своїх позицій у групі, збільшення кількості та якості особистих контактів у соціальній мережі.

Мінірівень. На цьому рівні соціальний капітал представлений функціонуванням домогосподарств (сімейних підприємств), діяльність яких побудована на довірі, на певних нормах поведінки, звичаях і традиціях. Це дає можливість об’єднати зусилля членів даної мережі (сім’ï) та досягти поставлених цілей. Сімейний соціальний капітал спонукає до утворення сімейних підприємств (домогосподарств), які приносять користь як самій сім’і, так i державі.

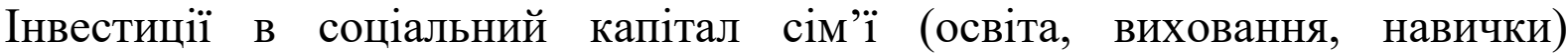
переходить в інвестування групового соціального капіталу, що для соціальної мережі є досить важливим, оскільки поведінка акторів є передбачуваною і може бути відкоректована іiі ж членами. Довіра на мінірівні формує загальні цінності.

Мікрорівень. На цьому рівні соціальний капітал розглядається 3 позиції фірми чи організації, він впливає на ефективну діяльність фірми через зниження трансакційних витрат, тим самим стає чинником довгострокового розвитку підприємств будь-якої галузі.

Мезорівень. Накопичуючись, на регіональному рівні соціальний капітал безпосередньо впливає на стабільність усієї соціально-економічної системи країни, він проявляється в об’єднаннях профспілок, громадських організацій, політичних партій, громадських рухів страхових компаній регіонального рівня. 
Макрорівень. На цьому рівні соціальний капітал відтворюється за допомогою вироблених суспільством норм і цінностей у напрямку досягнення економікою громадського оптимуму і підвищення соціального добробуту через дії інституційного та нормативного середовища щодо забезпечення загальнодержавної співпраці в межах національних ринків та економічної системи загалом. Соціальний капітал на рівні держави проявляється через легалізовані об’єднання громадян і недержавні громадські організації.

Мегарівень. На цьому рівні соціальний капітал впливає на ефективність світогосподарських зв'язків через підвищення довіри до системи глобальних інститутів, зниження ризиків при здійсненні трансакцій i, відповідно, зменшення трансакційних витрат. Головними інститутами, що підтримують довіру до світової системи господарства, є діяльність транснаціональних корпорацій, найбільших інвестиційних банків і фондів, а також долар як резервна валюта [148]. Соціальний капітал на рівні суспільства проявляється в діяльності транснаціональних корпорацій, Світового банку, різного роду глобальних, міжнародного рівня організацій та інше.

Згідно із сучасною науковою думкою, економіка розглядається як еволюційна відкрита система, що зазнає постійного впливу зовнішнього середовища (культури, політичних умов, природи тощо) та реагує на них [125, с. 92]. Будь-яка система має свою структуру, яка визначає зв'язки між елементами. Розвиток економічної системи корегується особливостями всіх складових суспільного розвитку, основним серед яких є такі позаекономічні чинники: культура, менталітет, моральне та духовне виховання, дружба, довіра, репутація та ін. Тому нині є актуальною проблема дослідження позаекономічних інститутів, що впливають на процес відтворення соціального капіталу.

Розквіт економічної системи в кожній країні корегується особливостями всіх складових суспільного розвитку, серед яких є позаекономічні чинники, такі як норми, стан моральних і духовних цінностей, культура, ментальність населення, взаємовідносини та взаємозв'язки тощо. Проблема стабільного суспільного розвитку пов'язана із взаємозалежністю економічних і природних 
факторів. Саме позаекономічні чинники значною мірою визначають суспільне відтворення та впливають на економічну рівновагу.

У табл. 4 показано вище розглянуті рівні соціального капіталу, на їх основі зобразимо коло накопичення відповідно до рівнів та позаекономічні чинники їх відтворення.

Таблиия 4

Рівні накопичення соціального капіталу та позаекономічні чинники їх відтворення

\begin{tabular}{|c|c|c|c|}
\hline Piвнi & $\begin{array}{c}\text { Рівні } \\
\text { накопичення } \\
\text { соціального } \\
\text { капіталу }\end{array}$ & $\begin{array}{c}\text { Коло } \\
\text { накопичення }\end{array}$ & $\begin{array}{c}\text { Позаекономічні чинники } \\
\text { відтворення }\end{array}$ \\
\hline 1 & 2 & 3 & 4 \\
\hline Нанорівень & $\begin{array}{c}\text { Наносоціальний } \\
\text { капітал }\end{array}$ & індивід & індивідуальний розвиток. \\
\hline Мінірівень & $\begin{array}{l}\text { Мінісоціальний } \\
\text { капітал }\end{array}$ & сім'я & $\begin{array}{c}\text { взаємовідносини в сім’ї; } \\
\text { моральне та духовне } \\
\text { виховання; } \\
\text { освіта. }\end{array}$ \\
\hline Мікрорівень & $\begin{array}{c}\text { Мікросоціальний } \\
\text { капітал }\end{array}$ & $\begin{array}{l}\text { друзі, } \\
\text { колеги }\end{array}$ & $\begin{array}{c}\text { дружба; } \\
\text { авторитет; } \\
\text { репутація. }\end{array}$ \\
\hline Мезорівень & $\begin{array}{c}\text { Мезосоціальний } \\
\text { капітал }\end{array}$ & $\begin{array}{l}\text { регіон, } \\
\text { галузь }\end{array}$ & $\begin{array}{c}\text { участь } \\
\text { у різного роду недержавних } \\
\text { громадських організаціях. }\end{array}$ \\
\hline Макрорівень & $\begin{array}{c}\text { Макросоціальний } \\
\text { капітал }\end{array}$ & держава & $\begin{array}{c}\text { демократія; } \\
\text { менталітет народу; } \\
\text { релігія. }\end{array}$ \\
\hline Мегарівень & $\begin{array}{l}\text { Мегасоціальний } \\
\text { капітал }\end{array}$ & суспільство & $\begin{array}{c}\text { демократія; } \\
\text { довіра світового масштабу. }\end{array}$ \\
\hline
\end{tabular}

Джерело: розроблено автором 
Через усю мережу позаекономічних чинників наскрізно можна прослідкувати 3 основних складових елементи соціального капіталу (соціальні мережі, норми та цінності, довіра), розглянемо їх докладніше:

менталітет - це результат розвитку суспільства, що втілює базові норми та цінності, за допомогою яких він був сформований. Отже, менталітет формується за допомогою норм $i$ изінностей, що панують у цьому суспільстві;

звички та стереотипи мислення - людина діє на основі самопідтримувальних соціокультурних норм, а це іє звички та стереотипи;

$>$ довіра виникає в рамках певного суспільства i включає мотиви взаємовідносин і готовність вести себе нормально та чесно, відповідно до прийнятих у суспільстві норм. Довіра породжує розвиток соиіальних мереж;

$>$ освіта основана на взаємодії соціальних спільнот для досягнення загальних цілей у вихованні та навчанні, ця взаємодія спричиняє утворення певних соичіальних мереж;

релігія є системою соціальних норм і духовних цүінностей. У результаті взаємодії людей у межах будь-якої релігії відбувається формування соціальної мережі між віруючими. Релігійна людина має жити за правилами і встановленими нормами та притримуватися визначених цінностей. Релігія породжується системою суспільних відносин;

культура - це сукупність цінностей (духовних, матеріальних і нематеріальних) та норм поведінки, притаманних конкретному суспільству; це структурний елемент соціальних відносин. Культура - це соціальний механізм взаємодії, що передбачає передачу 3 покоління в покоління цінностей, норм поведінки, традицій, звичок тощо.

Залежно від контексту соціальний капітал вимірюють різними способами. Виміряти його досить важко, оскільки це нематеріальне благо. Для цього використовують показники належності до громадських чи недержавних організацій, членство в асоціаціях і клубах, рівень довіри до певних інституцій, рівень дотримання норм та ін. 
Також важливим альтернативним показником вимірювання соціального капіталу є соціологічні опитування. Серед міжнародних дослідницьких проектів, що займаються вивченням цінностей та їх впливів на життєдіяльність людини, вимірювання соціального капіталу здійснює Всесвітнє дослідження цінностей (World Values Survey). Розрахунок рівня соціального капіталу відбувається за допомогою статистичних органів у країнах Великобританії, Австралії та ін., а координують національні програми 3 вимірювання соціального капіталу Всесвітній банк, ЮНЕСКО.

В Україні обчислення рівня соціального капіталу відбувається за допомогою даних соціологічних опитувань, що проводять «Центр Розумкова» та фонд «Демократичні ініціативи» імені Ілька Кучеріва, що дають можливість визначити та дослідити рівень довіри, межі дотримання норм і цінностей, включеність у соціальні мережі, громадську активність.

При вимірюванні соціального капіталу постає ряд перепон, головна 3 них це неоднорідність самої структури соціального капіталу, тому науковці вдаються до досвіду вивчення його кількісних, якісних і порівнювальних характеристик на різних рівнях.

У більшості випадків вимірювання соціального капіталу зводиться до вимірювання рівня його складових елементів - довіри, щільності соціальних мереж, норм і цінностей. Це досить складне завдання, оскільки при його вимірюванні необхідно оперувати різними індексами, що характеризують бажання (можливість) до самоорганізації.

\section{Соціальний капітал = Соціальні мережі + Довіра + Норми та цінності}

Вимірювання соціального капіталу здійснюється за:

- ступенем належності до певної мережі (особа має відчувати себе частиною певної мережі). Соціальний капітал не $\epsilon$ власністю окремих осіб, він виникає і відтворюється тільки в системі відносин між людьми. Він є ресурсом обмеженим, оскільки соціальні мережі мають здатність до замкнутості (нерівний доступ до соціальних мереж); 
- щільністю мереж зв’язків між людьми (щільність основана на довірі);

- встановленням відносин та взаємозв'язків між членами мережі, які побудовані на встановлених нормах і цінностях.

С. А. Сисоєв запропонував вимірювати соціальний капітал за 2-ма рівнями (мікро- та макро-), застосовуючи для цього кількісні та якісні методи вимірювання. На мікрорівні економічної системи суспільства при вимірюванні соціального капіталу автор пропонує звернути увагу на:

- виявлення взаємозв’язку між рівнем соціального капіталу та рівнем однорідності членів мікрогрупи по доходу;

- дослідження ступеня залучення окремих людей у механізм прийняття рішень, що торкаються інтересів усіх членів мікрогрупи;

- визначення можливості об’єднання членів мікрогрупи для здійснення колективних дій ;

• розрахунок рівня довіри всередині групи чи спільноти.

Вимірювання соціального капіталу на макрорівні автор пов'язує 3 пошуком закономірностей між об’ємом накопиченого соціального капіталу і темпами економічного зростання. При використанні кількісних методів дослідження можуть бути використані дані, зібрані національними статистичними органами чи міжнародними організаціями, а також у ході репрезентативних опитувань. Наприклад, репрезентативне опитування дозволяє отримати кількісні дані про оцінку респондентами того чи іншого явища, їх ставлення до нього. Опитування може охоплювати як жителів невеликого населеного пункту, так і жителів декількох країн. Використання науково обгрунтованої методики та анкет, виконання правил при побудові вибірки гарантують, що дані, отримані в ході опитування, будуть репрезентативними. Вимірювання соціального капіталу кількісними методами обчислюють такі індекси: індекс довіри; індекс розвитку громадянського суспільства (підрахунок кількості різних громадських організацій, об’єднань та їх членів).

Для розрахунку індексу розвитку громадянського суспільства використовуються такі статистичні дані: інформація про групи, об’єднання та їх 
членів; показники ступеня політичної участі. Схожий спосіб для дослідження обсягу соціального капіталу в Америці у своїй роботі застосовує Р. Патнем [168, с. 78]. На його думу, виміряти рівень соціального капіталу можна на основі членства в громадських організаціях та індексу довіри [166], цей метод вимірювання вчені використовують і нині.

Дещо інший підхід було запропоновано Організацією економічної співпраці та розвитку, що дає визначення соціальному капіталу як сукупності мереж i сумісної участі, цінностей і порозуміння, які полегшують взаємодію у групах та між ними, що обумовило формування показників, згрупованих за трьома напрямками: формальні мережі, неформальні мережі та довіра. Формальні мережі визначаються такими показниками: ступінь участі в асоціаціях, клубах, політичних партіях, профспілках, релігійних організаціях. Неформальні мережі визначаються такими показниками: рівень товариськості, частоту контактів i надання безвідплатної допомоги.

Зразок використання індексів соціального капіталу можна побачити у працях Ф. Фукуями, він застосовує для вимірювання кількості соціального капіталу показники, які можна представити у вигляді (1):

$$
\mathrm{SC}=(1 / \mathrm{rn}) * \mathrm{rp} * \mathrm{c} * \mathrm{n}) 1 \ldots \mathrm{t},
$$

де rn - «радіус недовіри», що характеризує зовнішнє враження суспільства про ту чи іншу групу (громадську організацію);

rр - радіус довіри;

c - «міра єдності» та внутрішні зв’язки існуючих груп;

n - сума (величина) різноманітних груп у суспільстві;

$\mathrm{t}$ - час виміру.

Якщо радіус довіри поширюється на всю групу, то коефіцієнт rр дорівнює 1. Проте великі групи n можуть мати низький коефіцієнт rp. Буває таке, коли, наприклад, релігійні общини можуть мати коефіцієнт rp більше 1. Це відбувається тому, що в цих об'єднаннях взаємини побудовані на чесності, довірі між членами групи та за їі межами. Тому слід пам'ятати, що на більший рівень 
довіри мають вплив соціальні норми, цінності, відкритість, що панують у групі, а не розмір цієї групи.

Індекс rn доводить, наприклад, що високоорганізована екстремістська група (мафія, терористичні організації) може мати високі показники n i c , rp близьке до 1, але іï соціальний капітал буде негативним і постійно зменшуватиметься соціальний капітал усього суспільства. Тому чим вища частка кримінальних, екстремістських організацій, тим нижче обсяг соціального капіталу в такому суспільстві.

Результати якісних методів досліджень не можуть бути представлені в цифровому вираженні й обробленими за допомогою статистичних методів, проте вони дозволяють глибше зрозуміти досліджуване явище і генерувати нові ідеї. Для проведення кількісних досліджень можуть бути використані експертні опитування, глибинні інтерв’ю, фокус-групи та інші методи досліджень.

За методикою Ф. Фукуями, вимірювання соціального капіталу має здійснюватися на основі таких даних: злочинність, сімейний стан (одруження/розлучення, кількість дітей, народжених поза шлюбом), опитування про довіру та громадянські цінності. Вимірювання за такою методикою відбувається на основі порівняльного аналізу динамічних рядів, це дає можливість визначити тенденції зміни розміру соціального капіталу, що доречно в атмосфері, коли абсолютну оцінку соціального капіталу встановити складно.

На погляд П’єра Бурдьє, масштаби та щільність мережі соціальних зв’язків, які використовує індивід, обсяг економічного, культурного, символічного капіталу, який належить учасникам мережі, впливають на розмір соціального капіталу.

Інший спосіб вимірювання соціального капіталу запропонував Р. Роуз. Він базується на використанні даних опитування громадян про їхню участь у формальних і неформальних мережах, встановлює їхні цільові установки.

Нині у світі не існує загальних методик вимірювання рівня соціального капіталу. Проведений аналіз способів його вимірювання не дає нам змоги обрати найефективніший. Для його дослідження використовують результати 
загальнодержавних і регіональних соціологічних досліджень, що здійснюються на основі показників громадської діяльності та їх активності в цих мережах, рівень довіри до органів влади, включеність у релігійні організації та ін.

На нашу думку, за методикою Ф. Фукуями можна здійснити вимірювання соціального капіталу на 6-и рівнях: нано-, міні-, мікро-, мезо-, макро- та мегарівнях.

На нанорівні вимірюється особистісний внесок індивіда у власний розвиток.

На мінірівні вимірюється вклад соціального капіталу у благополуччя сім’ї, домогосподарств. Цей соціальний капітал за допомогою особистих зв’язків допомагає знизити трансакційні витрати в бізнесі, доступ до інформації, доступної на цьому рівні, підтримку рідних.

На мікрорівні вимірюється соціальний капітал на рівні фірми та організації (корпоративний соціальний капітал), тобто його вплив на ефективну роботу фірми, організації і місце індивіда (актора) у співтоваристві. На цьому рівні соціальний капітал зменшує трансакційні витрати в організаціях, що веде до їі ефективного розвитку.

Норми та цінності, притаманні цьому співтовариству, що підтримуються соціальним капіталом, можуть стати частиною певної ідентичності, під дією якої приймаються ті чи інші економічні ухвали. Проте це може діяти і негативно.

Підкреслимо, що соціальний капітал здатен відігравати для соціуму як позитивну, так i негативну роль. Члени корпоративних, закритих груп одержують певні переваги, однак активність таких об’єднань має вкрай руйнівну дію на суспільне життя загалом. Прикладами негативної кооперації між людьми є злочинні угруповання, екстремістські та терористичні організації. Утіленням негативного соціального капіталу є клієнтарні відносини [94] i поширення корупційних зв’язків, що стають неписаною практикою вирішення питань на тлі недовіри до органів державної влади [93].

На мезорівні вимірювання соціального капіталу здійснюється на регіональному рівні при дослідження ефективної робити регіональних органів 
влади, об’єднань галузевих профспілок, політичної культури, демократії на регіональному рівні.

У роботі «Створення працюючої демократії» Р. Патнем доводить до читача виняткову ефективність роботи регіональних органів влади та управління в нинішній Італії через наявність щільної «мережі громадянської активності», утвореної різноманітними «цивільними об’єднаннями». «Чим густіші мережі такого роду є в суспільстві, тим більше підстав сподіватися, що члени цього товариства зуміють разом працювати для загального блага ... Соціальний капітал, утілений у горизонтальних мережах громадянської активності, швидше зміцнює державу й економіку, а не навпаки. Міцне суспільство - міцна економіка; міцне суспільство - міцна держава» [167]. Якісне регіональне управління спричиняє накопичення соціального капіталу цього рівня.

На макрорівні вимірювання соціального капіталу здійснюється на рівні держави, у межах національних ринків та економічної системи.

Незважаючи на виявлену рангову кореляцію між соціальним капіталом і державним управлінням, економічна віддача на соціальний капітал залишалася гіпотезою до появи більш строгих емпіричних доказів, отриманих 3 використанням сучасних економетричних моделей [201]. Уперше такий аналіз зробили С. Нек і Ф. Кіфер, які оцінили регресійну модель, що зв’язує темпи економічного зростання держав 3 рівнем довіри, етичних норм і членства в асоціаціях. Їхнє дослідження показало, що «передаточним ременем» у механізмі зв’язку соціального капіталу з економічним зростанням служать інвестиції та державне управління. Отже, у встановленому взаємозв’язку існує вплив соціального капіталу на розвиток як по вертикалі, так і по горизонталі. Цей механізм по вертикалі забезпечує ефективнішу роботу державних органів, зміцнення формальних інститутів, що підтримує інвестиційну активність; а по горизонталі - сприяє поширенню інформації та довірі в робочому середовищі, що також підвищує якість життя населення, підтримує інвестиційну активність i соціальний добробут. 
На мегарівні вимірювання соціального капіталу здійснюється в розрізі показників економічного благополуччя (темпи росту економіки, рівень задоволеністю життям, наприклад у країнах Свросоюзу), рівня довіри до валюти (долар, євро), до великих інвестиційних банків, до транснаціональних корпорацій та ін.

У ряді робіт, виконаних з використанням більшої вибірки, панельних даних i різного роду інструментальних змінних і тестів робастності, переконливо підтверджена значна економічна віддача на соціальний капітал, що спостерігається на рівні країн. Характерно, що в цих роботах, як правило, вимірюється вплив соціального капіталу на ефективність формальних інститутів і державного управлення, повертаючи цей науковий напрямок до традицій, закладених Патнемом. Переважання такого підходу можна розглядати як неявне визнання більшої важливості вертикального механізму впливу соціального капіталу на економіку і суспільство порівняно 3 горизонтальним. Іншими словами, більшість авторів виходять 3 того, що в сучасному світі здатність суспільства до самоорганізації найбільш важлива і затребувана в забезпеченні підзвітності держави, а меншою мірою - в можливості заміщення держави (i інших формальних інститутів) у повсякденному житті людей [201].

Сильне громадянське суспільство сприяє соціально-економічному розвитку регіону, країни, світу (відповідно мезо-, макро- та мегарівні), що не можливо досягти без достатнього рівня соціального капіталу на нано-, міні- та мікрорівнях.

При вимірюванні рівня соціального капіталу необхідно звертати увагу на ряд індивідуальних характеристик (вік, освіта, належність до релігійних чи громадських організацій). Також слід пам'ятати, що у країнах можуть бути розбіжності в домінантності складових соціального капіталу (довіра, громадянська активність, толерантність, членство в асоціаціях, інвестиції).

Процес відтворення соціального капіталу - це динамічний і безперервний процес формування позаекономічних інститутів, що відбувається в замкнутому колі в сім'ї, групі, суспільстві. 
Відтворення соціального капіталу - це процес «побудови» різносторонніх взаємозв'язків і якісних соціальних мереж між економічними агентами (суб’єктами), заснованих на довірі, звичках, традиціях, цінностях, оскільки довіра та соціальні мережі відіграють важливу роль у розвитку економіки, у свою чергу рівень розвитку соціального капіталу впливає на економічний розвиток суспільства.

Слід пам'ятати, що суттєвий вплив на відтворення соціального капіталу виконують такі позаекономічні чинники (фактори), як:

- релігійні і культурні та ментальні особливості народу, групи, кола;

- зростання рівня довіри;

- збереження та відтворення необхідних звичок і стереотипів мислення;

- збільшення чисельності освічених людей.

Складний процес відтворення соціального капіталу можна спостерігати на нанорівні - 3 позиції особи; на мінірівні - з позиції сім’ї; на мікрорівні - $з$ позиції кола знайомих, друзів; на мезорівні - 3 позиції регіональних асоціацій, громадських організацій; на макрорівні - 3 позиції країни; на мегарівні - 3 позиції суспільства, міждержавних корпорацій, ТНК тощо.

Групи факторів відтворення соціального капіталу:

1. Фактори впливу наносередовища (відтворення соціального капіталу починається на рівні індивіда за допомогою знань, умінь і навичок).

2. Фактори впливу мінісередовища (відтворення соціального капіталу відбувається на рівні персоніфікованих відносин або взаємовідносин у сім’ї).

3. Фактори впливу мікросередовища (відтворення соціального капіталу на рівні взаємовідносин між друзями, колегами, організаціями).

4. Фактор впливу мезосередовища - це розширене коло відтворення регіонального рівня (дружні контакти, асоціації), різні взаємодії людини побудовані на довірчих відносинах.

5. Фактори впливу макросередовища - це насамперед розвиток інституціональної структури соціального капіталу на рівні держави (освіта, виховання, професійна підготовка). 
6. Фактори впливу мегасередовища (відтворення соціального капіталу на рівні міждержавних взаємовідносин, ТНК).

Останнім часом прослідковуються зміни в соціальних орієнтирах розвитку економіки, саме соціальний чинник є надзвичайно актуальним при дослідженні процесів соціалізації теперішньої ринкової економіки. Сьогоденні події засвідчують необхідність дослідження місця й ролі соціальних чинників (соціального капіталу) у системі економічного розвитку.

Соціалізація - комплексний процес засвоєння індивідом певної системи знань, норм і цінностей, які дозволяють йому бути повноправним членом суспільства. Соціалізація виступає одним 3 основоположних соціальних процесів, що забезпечує існування людини в суспільстві. Соціалізація являє собою процес входження людини в суспільство, включення її в соціальні зв’язки та інтеграції з метою встановлення ії соціальності [212]. Соціалізація економіки - це проникнення у сфери економічної і позаекономічної діяльності таких відносин, що сприяють поліпшенню добробуту населення як безпосередньо, так i опосередковано, через формування умов до самовираження людини [111]. Соціалізація соціально-економічних відносин - це процес соціалізації суспільного відтворення як об'єктивна закономірність економічного розвитку. Цей процес вимагає підтримки як з боку держави, так і з боку соціуму.

Економічний розвиток можливий 3 розвитком соціальним, однак досліджувати такий взаємозв'язок досить складно, оскільки проблематично встановити наслідки соціальних процесів. Взаємозалежність соціального та економічного розвитку є основою суспільного поступу.

Відтворення соціального капіталу можливе за умови інвестування, що в подальшому веде до отримання від користування соціальним капіталом специфічного доходу, який може бути визначений як частина соціальної ренти, пов’язаної з вигодою від соціального капіталу.

П. Бурдьє, Дж. Коулман, К. Маркс, Р. Патнем [98, с. 63, с. 72, с. 81] та інші соціальний капітал розглядають як вигоди, отримані суб’єктами (акторами) від певних взаємних дій 3 метою взаємовигідної співпраці, що досягається за 
допомогою обміну інформацією і дає можливість отримати значну соціальноекономічну вигоду та зниження трансакційних витрат у процесі їх господарської діяльності.

Загальне значення слова «рента» - це додатковий дохід, який отримує підприємець понад певний прибуток на затрачену працю і капітал; утворення ренти обумовлено сприятливішими умовами, у яких перебуває один підприємець порівняно з іншим, наприклад обробляє кращу ділянку землі, має привілей тощо [205]. Рента - легальний, регулярний дохід, який не потребує конкретної діяльності [100]. Існує визначення поняття «рента економічна»- особливий вид ренти у формі додаткового доходу, яку отримує підприємець унаслідок зменшення витрат на одиницю продукції порівняно з іншими виробниками [95].

Категорію «соціальна рента» ввели член-кореспондент Російської академії наук Р.С. Грінберг і професор А.Я. Рубінштейн. Досліджуючи теорії раціональної поведінки держави, вчені звернули увагу на негативний досвід проведення приватизації в Російській Федерації, коли певне коло осіб за заниженими цінами «прибрало» до своїх рук більшу частину національного багатства країни. На їхню думку, соціальна рента виникає при недотриманні принципів відповідності, зокрема: благо G, що перебуває у власності держави, володіє граничною індивідуальною корисністю MUG та граничною соціальною корисністю MSUG. За інших рівних умов дотримується принцип відповідності. Це означає, «що, окрім прямого доходу від використання блага окремими індивідуумами, державна власність на нього дозволяє реалізувати відповідні цільові установки суспільства, тобто забезпечує присвоєння в розмірі непрямого прибутку в розмірі граничної соціальної корисності MSUG» [110, с. 62]. Як наслідок суб'єкт господарювання стає власником блага G за ціною P1, яка дорівнює капітальному доходу від цього блага. Продажна ціна Р1 відповідає тільки граничній індивідуальній корисності MUG $(\mathrm{P} 1=\mathrm{MUG})$ і буде нижчою за повну ціну Р, оскільки в такій приватизаційній угоді не врахована гранична соціальна корисність блага MSUG. 
Тільки у двох випадках не порушується принцип відповідності: «По-перше, коли в оцінці капіталізованого доходу враховується не тільки індивідуальна, а й соціальна корисність блага. По-друге, якщо продаж держвласності за пільговою ціною (без урахування соціальної корисності) здійснюється одночасно 3 делегуванням новому власнику зобов'язань, виконання яких дозволить реалізувати відповідні цільові установки суспільства» [110, с. 62].

Підставою для отримання соціальної ренти є мережа соціальних зв'язків (належність до певної соціальної групи), взаємовідносини побудовані на довірі та дотриманні встановлених норм і цінностей.

На мікроекономічному рівні ренту розглядають як прибуток від володіння певним соціальним капіталом. На макроекономічному рівні відіграє свою роль держава як власник економічного простору, що створює певне інституціональне середовище та формуюче коло суб'єктів рентних відносин. Влада створює середовище, яке надає особливі вигоди «соціальним рантьє» порівняно 3 економічними агентами, які діють в інших умовах. У такому випадку влада може розглядатися як спроба перерозподілу ресурсів об'єднаними групами, котрі володіють специфічними статусними характеристиками. Ці відносини можуть мати й мегарівень, на якому одержувачами ренти і суб'єктами економічних відносин виступають держави [100].

Соціальна рента - це привласнення праці іншого, соціальне паразитування, коли таку можливість дає статус, підтверджений силою держави. Але навряд чи можна очікувати, що експлуатований віддасть частину своєї праці добровільно, нічого не вимагаючи натомість. Крім неприхованого насильства, застосування якого передбачається, але невигідне, оскільки очевидне і викликає або опір, або руйнування середовища, котре дає ренту, краще замаскувати відбирання [100]. Зовнішній позитивний ефект соціальної ренти полягає в тому, що частина сукупної користі блага безкоштовно отримують інші особи чи організації.

Соціальну ренту С. І. Діскін розкриває як частку прибутку, отриману за рахунок створення локального інституційного середовища. Отримана вона «за рахунок розвитку соціального порядку - використання соціального капіталу, 
накопиченого в даній країні або навіть у відповідному регіоні» [121, с. 14]. Соціальна рента - це вигоди, що здобуваються господарюючими суб'єктами 3 наявності соціального капіталу. Соціальну ренту отримують особи, організації, держави (відповідно до рівня накопичення соціального капіталу), тобто всі ті, хто діє у визначеному інституційному середовищі, що надає їм особливі вигоди порівняно з економічними агентами, що діють в інших умовах.

Погоджуючись із трактуванням М. В. Курбатової і Н. Ф. Опаріної [151], доцільно доповнити його відповідно до рівнів соціального капіталу джерелами, причинами та наслідками утворення ренти. У додатку А узагальнено та зображено розглянуті вище рівні накопичення соціального капіталу та соціальної ренти.

На нанорівні особа є колом накопичення соціального капіталу, джерелом соціальної ренти $є$ дохід 3 використанням якостей, що формується 3 індивідуальних навичок, а наслідком $є$ отримання знань, умінь, навичок i зниження соціальної вразливості індивіда.

Мікрорівень характеризується персоніфікованими відносинами, сімейними цінностями та нормами поведінки, що підкріплені особистою довірою, як і на нанорівні. Колом накопичення соціального капіталу $\epsilon$ сім’я. Джерелом соціальної ренти є дохід з використанням власних зв’язків і якостей, причиною виникнення $є$ родинні відносини. Вигодою при користуванні соціальним капіталом на цьому рівні є зниження трансакційних витрат.

На мікро- та мезорівні одним з типів взаємодії є раціональна довіра, колом накопичення відповідно на мікрорівні - друзі, колеги, організації, а на мезорівні - регіони, галузі. Наслідками на мікрорівні є привілейований доступ до певних ресурсів та інформації і зниження виробничих витрат, а на мезорівні - зниження трансакційних витрат для координації загальної діяльності в регіональному масштабі чи в межах галузі.

Макрорівень будується на відносинах у державі, а вже мегарівень - на міждержавних. На цих рівнях панує генералізована довіра. Джерелом накопичення соціальної ренти на макрорівні є прибуток, отриманий за рахунок 
створення локального інституційного середовища; на мегарівні - прибуток, отриманий за рахунок зростання довіри у світовому масштабі. Результатом цього процесу на макрорівні є підвищення довіри до держави, їі економічне зростання; на мегарівні - збільшення активності в зовнішньоекономічних відносинах і зростання ефективності світогосподарських мереж.

Виникнення соціального капіталу на рівні держави починається 3 побудови між суб’ єктами мережі соціальних відносин. Розвиток цих відносин базується на їх зміцненні та дотриманні спільних норм і цінностей цієї мережі, а це породжує виникнення довіри між іiі членами. Результатом цього процесу стає виникнення соціального капіталу. 3 позиції держави виникнення соціального капіталу здійснюється за допомогою позаекономічних інститутів: правових, політичних, ідеологічних, етичних. Розглянемо процес виникнення соціального капіталу за допомогою позаекономічних інститутів та отримання суб’єктом соціальних відносин специфічного прибутку (соціальної ренти) від користуванням капіталом (рис. 12).

\section{Процес виникнення соціального капіталу}

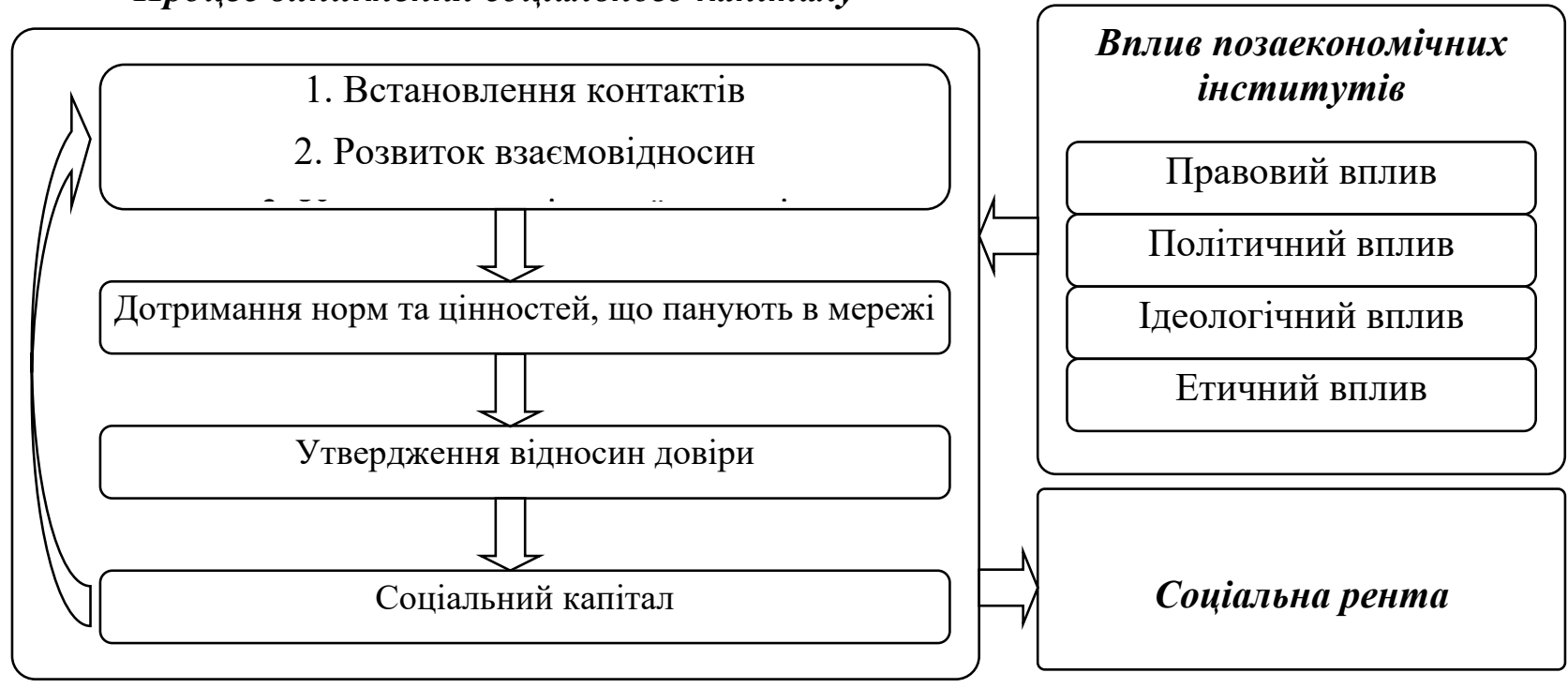

Рис. 12. Процес формування соціального капіталу та соціальної ренти Джерело: розроблено автором 
Кожен рівень накопичення соціального капіталу, розглянутий вище, допомагає виміряти ступінь вигоди отриманої контрагентами в результаті належності до тих чи інших соціально-економічних відносин.

Соціальний капітал в економічному процесі:

- збільшує обсяг ресурсів доступних для агентів соціального капіталу;

- зменшує трансакційні витрати;

- конвертується в інші форми капіталу;

- отримується соціальна рента.

На нашу думку, соціальна рента - це вигода, яку отримує суб'єкт від володіння соціальним капіталом. Розмір соціальної ренти буде залежати від розміру трансакційних витрат і від обсягу розподілу їх між суб'єктами обміну [212].

Входження соціального капіталу в економічну сферу опосередковується капіталізацією соціальності (соціальних зв'язків), тобто трансформацією соціального блага в соціальну ренту (рис. 13).

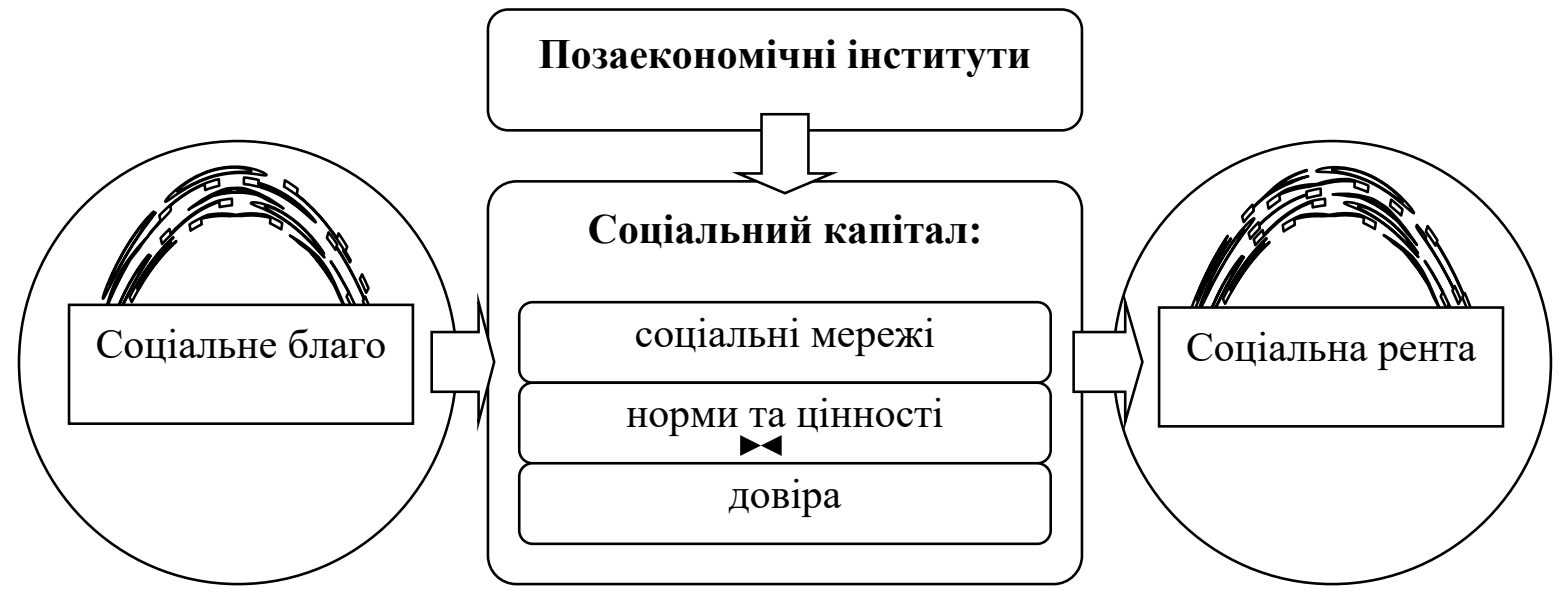

Рис. 13. Вплив позаекономічних інститутів на конвертацію соціального капіталу та утворення соціальної ренти

Джерело: розроблено автором 
Отже, інвестування в соціальний капітал веде до його відтворення, що уможливлює отримання специфічного доходу - соціальної ренти. Цей процес можливий за допомогою використання позаекономічних інститутів, у результаті чого в соціальній системі конвертація соціального капіталу як соціального блага веде до утворення в економічній соціальної ренти.

Світова спільнота все частіше визнає той факт, що рівень соціального капіталу є одним з головних індикаторів, які впливають на економічний розвиток суспільства, держави, регіону, організації, сім’ї. У свою чергу соціальнокорпоративний капітал (корпоративний соціальний капітал) є не менш важливим фактором ефективного функціонування організації і стоїть в одному ряді 3 факторами виробництва, науково-технічним прогресом та ін.

У цьому параграфі розкриємо сутність соціального капіталу на рівні організації, іншими словами - соціально-корпоративний капітал. Кожна окрема людина більше пов'язана 3 тією соціальною організацією, у якій вона співпрацює, а вже потім - із суспільними процесами. Соціально-корпоративний капітал організації складається із соціального капіталу працівників, або членів організації. Відтворення соціально-корпоративного капіталу в організації впливає на процес ефективного ведення та організації власної справи, збільшення продуктивності праці та ефективності соціально-економічної політики даної організації, знижує витрати на ведення економічної діяльності загалом.

У науковій літературі спостерігаємо збільшення зацікавленості до соціального капіталу. Усе більше прослідковується інтерес до вивчення зв'язків у життєдіяльності людини та організації. Людські відносини є головним ресурсом соціального капіталу, а концепція соціального капіталу полягає в тому, що соціальні мережі складають основу для соціальних зв'язків, оскільки в соціальних мережах люди об'єднуються одне з одним для досягнення певних цілей і в кінцевому результаті отримання соціальної ренти (вигоди).

Соціально-корпоративний капітал - це соціальний капітал організації, що утворюється і нагромаджується на мікрорівні (на рівні організації). Головна його 
функція полягає у збільшенні завдяки мережам кількості доступних ресурсів (володіти ресурсами, якими ще не володів) для членів організації та зменшенні витрат як самої організації, так і їі членів з отриманням такого доступу.

На нашу думку, соціально-корпоративний капітал - це нематеріальний капітал (ресурс) організації, який оснований на міцних мережах, довірі, нормах та цінностях і забезпечує ii ефективне функціонування та отримання соціальної ренти корпоративними акторами.

Соціально-корпоративний капітал допомагає прогнозувати майбутнє та уникати конфліктів за допомогою передбачуваності і прозорості поведінки акторів, знижує невизначеність і трансакційні витрати організації.

Уперше в науковий обіг поняття «корпоративний соціальний капітал» ввели в 1999 p. американські дослідники Ш. Габбей і Р. Ліндерс у книзі «Корпоративний соціальний капітал та відповідальність», визначаючи його як «набір ресурсів, які відчуваються або не відчуваються, проте накопичуються корпоративним гравцем через його соціальні відносини, полегшуючи йому досягнення цілей». За їхнім визначенням, соціальний капітал є результатом соціальних мереж, а не їх структурним проявом, у свою чергу мережі породжують цінність.

Ф. Фукуяма зазначає, що соціальний капітал може існувати як у малому осередку, як на рівні великого колективу, так і в межах будь-якої з проміжних груп. Соціально-корпоративний капітал сприяє ефективному функціонуванню колективу організації, впливає на успішність кар'єри, ріст репутації, передбачуваності організаційної поведінки, знижує плинність особового штату організації, збільшує продуктивність праці.

Структура соціально-корпоративного капіталу, як і соціального капіталу, включає такі складові: мережі, норми і цінності та довіра на мікрорівні.

На процес відтворення соціального капіталу організації впливає кількість, розмір і щільність соціальних мереж; довіра, яка покращує відносини в організації, зменшує вірогідність конфліктних ситуацій, допомагає у прийнятті 
суперечних рішень. Відносини, побудовані на довірі, $є$ більш тривалими, вона $€$ чинником зростання соціально-корпоративного капіталу.

Розглянемо зміст елементів соціально-корпоративного капіталу: соціальні мережі, довіра, норми та цінності мікрорівня. Соціальні мережі є головною структурною основою соціального капіталу. Д. Коен і Л. Прусак вважають, що мережі є основним джерелом почуття причетності до організації і зобов’язань, тобто такого становища в організації, коли люди відчувають себе як удома i відповідальні одне за одного. Мережі в більшості випадків будуються між індивідами відділу, підрозділу загалом в організації, що допомагає розвитку соціального капіталу на підприємстві. За мережевою теорією соціальний капітал $€$ ефектом соціальних мереж i поширює принципи мережевого аналізу на вивчення процесів відтворення соціального капіталу.

Реалізація учасниками мережі своїх зобов'язань один перед одним не означає, що кожний суб'єкт упевнений в індивідуальній чесності своїх партнерів по мережі. Мережевий світ змушує індивіда дотримуватися умови взаємодії [90, c.53]. Соціальний капітал знаходиться у структурі мережевих економічних взаємодій, у результаті чого його можна показати як систему відносин, побудовану на довірі. Тому чим густіші економічні мережі, тим швидше розвивається соціальний капітал, тобто збільшення соціального капіталу відбувається за рахунок збільшення кількості економічних зв'язків, побудованих на довірі.

Розглянемо соціальний капітал з позиції теоретичної традиції як властивість соціальної структури, представлену у вигляді соціальних мереж. Головним завданням при цьому виступає дослідження способів, за допомогою яких соціальні мережі реалізують функцію соціального капіталу. 3 цієї позиції соціальний капітал виступає як сукупність соціальних норм і цінностей, об’єднання людей у колективи та ведення ефективної колективної діяльності на підприємстві чи організації.

У статті «Соціальний капітал. Значення поняття» М. Вулкок указав на те, що «сім’я, друзі, асоціації складають разом одну цінну характеристику - можуть 
вистояти разом у кризу і досягти матеріальних цінностей, - зробити це для решти людей. Такі спільноти складають основний фонд соціальних зв’язків i цивілізованих асоціацій. Вони можуть протистояти конфронтаційному суспільству та вразливості». Міжособистісні зв'язки для М. Вулкока є ресурсом соціального капіталу. У кризовий період при злагодженій роботі та щільній соціальній мережі, побудованій на довірі колективу організації (підприємства), поведінка членів мережі стає передбачуваною. У таких умовах організація (підприємство) може економити на трансакційних витратах i вистояти у кризовий період.

Б. Уцци робить акцент, що «організаційні мережі працюють в укоріненій логіці обміну, що стимулює економічну ефективність через міжфірмові ресурсні партнерства, співробітництво і координовану адаптацію, але може, навпаки, погіршувати економічні показники, закриваючи компаніям - членам мережі доступ до нової інформації і можливостей за межами мережі. Місце організації в мережі, структура цієї мережі і розподіл укорінених відносин обміну впливають на ефективність таким чином, що вона досягає свого піка економічних показників у міру зростання ступеня вкорінення в мережі. Після проходження цієї точки вкорінення призводить до зворотного, негативного ефекту».

Дж. Коулман у праці «Підстави соціальної теорії» [148] зосереджує увагу на важливості створення добровільних суспільних об’єднань, взаємозв’язки в яких є здебільшого неформальними (позаекономічними) і грунтуються на довірі, а також взаємній підтримці, що підштовхує до розширення мережі контактів та збільшення соціального капіталу.

На думку В. В. Радаєва, соціальний капітал спрощує процес створення нових підприємств, що приводить до розвитку підприємництва, а це веде до підвищення ефективності ринку [204]. Завдяки довірі, нормам, цінностям, підтримуваним соціальними мережами, у суспільстві затверджуються чіткі зразки взаємодії. 
Дослідження соціальних мереж займає значне місце в концептуалізації соціального капіталу. Взаємозв'язки між економічними агентами (індивід, організація, держава), що складаються в межах інститутів, мають свою структуру. Структура взаємовідносин - це мережа, яка пов’язує між собою всіх своїх учасників.

Мережі - це первинний прояв взаємозв'язків між людьми, вони виступають як формою, так і джерелом соціального капіталу. Самі по собі мережі не $є$ соціальним капіталом, ним вони стають лише в тому випадку, коли використовуються з користю і цілеспрямовано. Корисність мереж проявляється в тому, що актор отримує певну вигоду або, іншими словами, частину соціальної ренти.

В інституціональній теорії мережу визначають як сукупність зв'язків між групою економічних агентів, які знаходяться один з одним у тих чи інших відносинах.

Інтерес до соціальних мереж виник тільки тоді, коли досить сильно стали проявлятися в усіх сферах суспільного життя інтегративні, об’єднуючі тенденції, що врівноважують протилежні тенденції до поділу і диференціації. Форма соціальної мережі допомагає визначити ступінь своєї корисності для ії̈ учасників. Менші, більш зв'язані мережі можуть бути менш корисними для своїх учасників, ніж мережі з багатьма слабкими зв'язками з особами ззовні від основної мережі. «Відкритіші» мережі, 3 багатьма слабкими зв'язками та соціальними взаєминами, вірогідно, будуть пропонувати нові ідеї та можливості для своїх учасників, аніж замкнені мережі з багатьма надлишковими зв'язками. Іншими словами, група знайомих, друзів, які спілкуються лише один з одним, вже володіють спільними знаннями та можливостями. Група осіб із зв'язками 3 іншими соціальними спільнотами, вірогідно, отримуватиме доступ до ширшого діапазону інформації. Для досягнення успіху індивідам краще мати зв'язки 3 декількома мережами, аніж багато зв'язків у межах однієї. Аналогічно індивіди можуть впливати або діяти в ролі брокера всередині своїх соціальних мереж, з'єднуючи дві мережі, у яких відсутні безпосередні зв'язки (має назву 
заповнення соціальних дір) [213]. Соціальні мережі - це соціальна структура, що складається з людей (акторів), які можуть бути пов'язані дружбою, цінностями, поглядами тощо.

Соціальні мережі в організації впливають на формування і структуру соціально-корпоративного капіталу, на формування як економічних зв'язків (економічних угод), так і позаекономічних (родинні зв'язки, знайомства, належність до певної групи, об’єднання). Учасники мереж у будь-якій сфері діяльності зацікавлені залишатися членами соціальної мережі, тому що вона підтримує ефект співвідношення вигоди та ризику при здійсненні трансакцій з іншими агентами, чинними в цій мережі.

За допомогою мереж відбувається реалізація соціального та економічного капіталу, а також їх конвертація в соціальну ренту. Такі мережі виступають джерелами інформації та довіри. В основі виникнення соціальної ренти лежать соціальні мережі, які обумовлюють здатність людей до ефективної взаємодії.

Соціальна рента - це специфічна форма доходів, які отримують колективно. Соціальну ренту мають лише ті спільноти, які вже накопичили соціальний капітал.

Джерелами формування соціальної ренти є:

- зниження трансакційних витрат;

- збільшення конкурентоздатності держави, регіону, організації та ін.;

- економічна вигода від членства в соціальній мережі;

- володіння необхідною інформацією;

- соціалізація працівників в організації.

Єдність економічного і соціального аспектів дає можливість ефективно регулювати діяльність організації, регіону та країни.

Проте слід пам'ятати, що занадто замкнені співтовариства іноді стають жертвою колективної ненависті і призводять до обману, тобто вони можуть стати «зв’язками, що засліплюють». Досить часто в науковій літературі під поняттям 
«мережа» розуміють (вживають) термін «співтовариства», однак потрібно пам'ятати, що ці поняття не завжди є тотожними.

Соціальні мережі не мають організаційної структури і проявляються в неформальних взаємозв'язках. Досить часто соціальні мережі компенсують неефективність формальних інститутів. Процес формування соціальних мереж відбувається за допомогою таких принципів (рис. 14):

- ініціативності для вибору входження до соціальної мережі;

- переслідування мети досягнення певного результату;

- зменшення трансакційних витрат;

- системності в отриманні необхідної інформації.

Сукупність довіри, норми і цінності, що діють у соціальній мережі, на мікрорівні веде до збільшення та відтворення соціально-корпоративного капіталу.

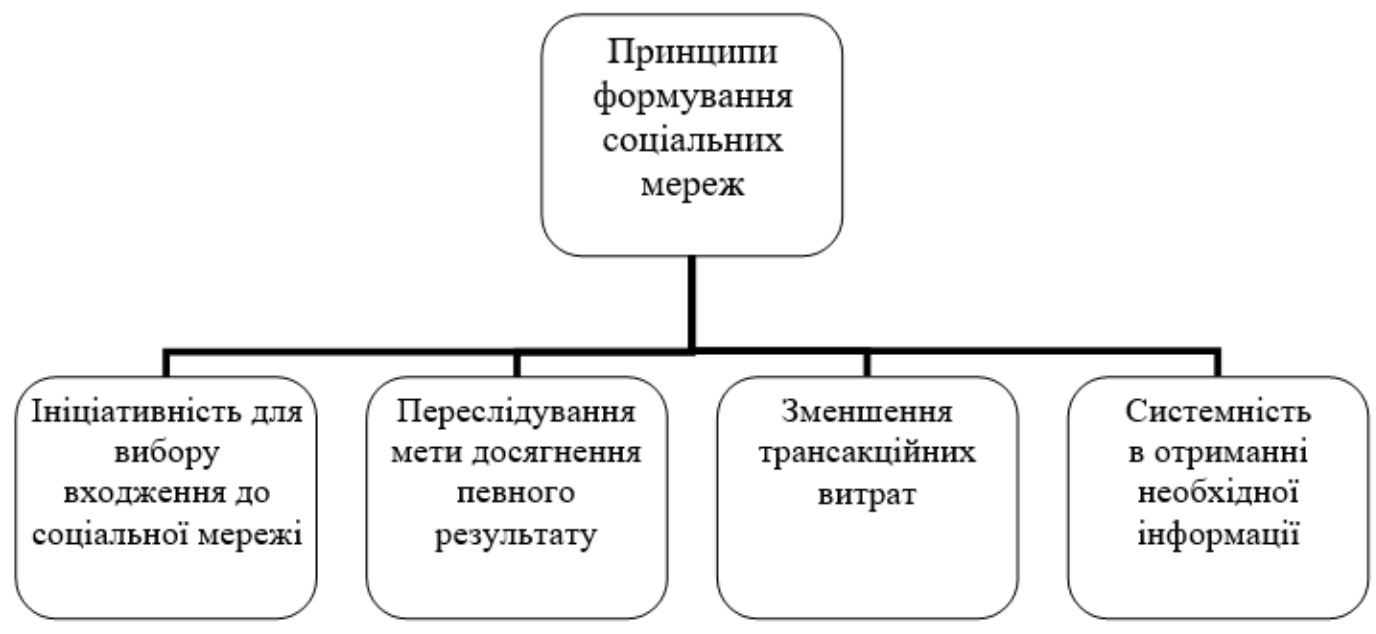

Рис. 14. Принципи формування соціальних мереж за рядом ознак

Джерело: розроблено автором

Соціальні мережі класифікують за різними ознаками: за рівнями створення, за структурою, за рівнем знаходження, за масштабами, за причиною виникнення. Кожна з цих ознак має власні характеристики, тому детальніше розглянемо класифікацію соціальних мереж у табл. 5. 
Класифікація соціальних мереж

\begin{tabular}{|l|l|c|}
\hline № п/п & Ознака & Характеристика \\
\hline 1. & За рівнями створення & Мікрорівень \\
& & Мезорівень \\
& & Макрорівень \\
\hline 2. & За структурою & Слабкі мережі \\
& Сильні мережі \\
\hline 3. & За рівнем знаходження & Горизонтальні мережі \\
& За масштабами & Вертикальні мережі \\
\hline 4. & Суспільні мережі \\
\hline 5. & За причиною виникнення & Міжнародні мережі \\
& & Родинні \\
& & Групові \\
& & Регіональні \\
& & Державні \\
& & Суспільні \\
\hline
\end{tabular}

Джерело: розроблено автором

Соціальні мережі відіграють важливу роль у відтворенні соціальнокорпоративного капіталу, $\epsilon$ його магістральним структуроутворюючим компонентом, що зумовлює утворення його в кожній організації. Соціальні мережі надають індивідам (акторам) доступ до ресурсів і забезпечують внутрішню (моральну) та організаційну допомогу.

Наступним компонентом соціально-корпоративного капіталу є довіра. М. Грановеттер твердить, що довіра утворюється тоді, коли угоди вкорінені в межах структури особистих відносин і соціальних мереж, що за допомогою соціальних відносин відбувається виробництво довіри. Соціальний капітал, як фізичний і людський капітали, полегшує виробничу діяльність. Група, у середині якої повна надійність і абсолютна довіра, здатна зробити значно більше, ніж група, що не володіє цими якостями. Через переваги в доступі до ресурсів соціальний капітал впливає на ефективність діяльності організації, суспільства, 
тобто соціальний капітал дозволяє швидше одержувати необхідну інформацію, скоріше знаходити фінансову, дипломатичну й суспільну підтримку для запланованих проектів.

«Довіра - це поява у членів суспільства очікування того, що інші його члени будуть вести себе більш-менш передбачувано, чесно і з увагою до потреб оточуючих, у згоді з деякими громадськими нормами». На думку Ф. Фукуями, довіра виступає основним джерелом соціального капіталу, оскільки «соціальний капітал - здатність, що виникає з поширення довіри в суспільстві або певних його частинах».

Б. 3. Мільнер розглядає довіру на макрорівні (суспільство) та на мікрорівні (організація), зазначаючи, що нині довіра набирає економічного значення, оскільки підвищення рівня довіри між соціальними суб'єктами веде до зменшення сукупних суспільних витрат. На його думку, механізм довіри в економіці базується на психології довіри кожного індивіда і групи. Вивчаючи роль та значення довіри в організації та між організаціями, Б. З. Мільнер зазначає, що довіра має стати ключовим принципом взаємовідносин між різними структурними підрозділами компанії [159]. Коли в організації зміцнюється та збільшується рівень довіри, відбувається і збільшення рівня соціального капіталу. С. Касталдо підкреслює, що «...мережа не тільки вимагає довіри, щоб бути скоординованою і ефективно діяти, але також здатна обумовити процеси формування довіри, стаючи його генератором». Проте він відносить до джерела довіри також норми і цінності, які є всередині мереж.

Довіра - це показник надійності в певних визначених межах (групах, організаціях, співтовариствах та інше). Ж. Нахапет і С. Гошал вважають, що «довіра сприяє співробітництву, а співробітництво породжує довіру». Е. Лессер і Л. Прусак доводять, що «довіра являє собою окреме поняття і може бути як джерелом соціального капіталу, так і його результатом». Звідси можна зробити висновок, що довіра є джерелом, складовою і результатом соціального капіталу. Таке твердження $є$ досить вагомим для дослідження соціально-корпоративного капіталу. 
А. В. Філіппов твердить, що етика ділових відносин базується на правилах поведінки партнерів, які сприяють розвитку співпраці та орієнтовані на розвиток взаєморозуміння і довіри. Значення цих правил полягає в інформуванні партнера про свої наміри та дії, а також унеможливленні зради і навмисної дезорієнтації. Передбачувана і відкрита поведінка учасників мереж в організації є запорукою довірчих відносин у середині цієї мережі. Довіра на рівні організації (міжособистісна, групова) є досить важливою, оскільки в цих організаціях може утворюватися «солідарність», за допомогою якої члени організації слідують поставленим цілям і досягають накреслених результатів.

Відтворення соціально-корпоративного капіталу через механізм довіри відбувається за допомогою:

- довіри між партнерами взаємовідносин;

- довіри всередині організації (підприємства) між керівниками кожного підрозділу, між структурними підрозділами, між працівниками, а також довіри керівництва до підлеглих і навпаки;

- довіри всіх членів організації до встановленої цілі (мети) діяльності організації;

- довіри до профспілки;

- довіри до регулюючих чи контролюючих органів.

Джерелом довіри на підприємстві (в організації) можуть виступати такі чинники:

- захищеність інтересів працівників як 3 боку держави, так і 3 боку керівництва;

- чітке слідування встановленим нормам та правилам в організації;

- партнерські відносини;

- відкрита діяльність організації;

- встановлення чітких i доступних цілей діяльності організації (підприємства);

- відданість і чесність усіх працівників і керівників (репутація). 
За словами Дж. Андерсон і А. Нарус, довіра в організації - це «віра фірми, що інша компанія виконає дії, які приведуть до позитивних результатів для фірми, так само як не зробить несподіваних дій, що призведуть до негативних результатів». Довіра в організації веде до розвитку партнерських відносин, ефективного командного функціонування, а також до зниження трансакційних витрат усередині організації (витрати на пошук інформації, укладання контрактів, ведення переговорів та інше).

Проте позаекономічні інститути ніколи не забезпечують повного обмеження всіх випадків опортуністичної поведінки. Г. Беккер розкрив принцип проблеми недотримання правил і законів загалом: людина зловживатиме довірою своїх контрагентів і порушить правила (закони) тоді, «якщо очікувана корисність від цієї дії перевищує корисність, яку він міг би отримати, використовуючи свій час і сили іншим чином» [92, с. 293]. При стійких відносинах соціальний капітал зменшує невизначеність i запобігає опортуністичній поведінці учасників мереж економічної взаємодії. Саме такий позаекономічний інститут з позиції одиничного, як довіра, зможе обмежити опортуністичну поведінку. Ефективність використання соціального капіталу відповідає рівню організації економічної мережі.

Наступним елементом соціально-корпоративного капіталу $є$ норми $i$ цุiнності, за допомогою яких формуються основи поведінки в організації. Норми $\epsilon$ первинним елементом соціального капіталу і факторами, що підтримують соціальні мережі. За допомогою норм можна керувати великою кількістю різних процесів: правосуддя, укладання угод і контрактів та інше. Дж. Коулман вважав, що норми можуть стати потужною формою соціального капіталу, який не тільки полегшує певні дії, але й стримує інші (негативні) тенденції. На його думку, соціальний капітал формується за допомогою неринкових сил - держави або громадських інститутів.

Організація має функціонувати як єдина мережа (команда), притримуючись установлених норм і цінностей, а це у свою чергу буде знижувати ступінь опортунізму і допоможе зробити прозорою поведінку співробітників. 
Досліджуючи норми загальної взаємності, Р. Патнем дає їм таке визначення: це «тривалі відносини обміну, які в кожен момент часу не винагороджені і не врівноважені, але які містять взаємні очікування, що вигода, отримана зараз, буде відплачена в майбутньому» [169]. Тобто учасники тієї чи іншої мережі, роблячи якусь послугу, очікують у майбутньому отримати певну вигоду (соціальну ренту).

Соціальні норми - загальноприйняті правила поведінки, які координують взаємодії людей. Норми дають індивідам у певній соціальній групі можливість діяти однорідно. Якщо норми через певні обставини змінюються, то відповідно змінюється і поведінка акторів у межах цієї групи.

Цінності за допомогою норм упроваджуються в життя і допомагають індивіду обрати ту чи іншу модель поведінки. Спільні цінності в організації (корпоративні цінності) згуртовують працівників за поглядами, за діями, за переконаннями, що приводить до прискореного та ефективного досягнення цілей організації. У свою чергу в процесі діяльності організації корпоративні цінності, яких притримується кожен працівник організації, приводять до виникнення довіри, яка об’єднує організацію в єдине ціле.

Дотримання індивідом певних норм, що передаються 3 покоління в покоління, веде до відтворення соціального капіталу.

Такі позаекономічні чинники, як культура, виховання, ментальність, стереотипи мислення, підкріплюють довіру, виконують це шляхом застосування санкцій до суб’ єктів економічної діяльності.

Соціально-корпоративний капітал може бути внутрішній (всередині організації) та зовнішній (відносини 3 іншими організаціями). Внутрішній соціально-корпоративний капітал відтворюється за допомогою особистісних взаємовідносин у середині організації (норми та традиції, що регулюють роботу певної соціальної мережі, репутація кожного працівника, різного роду творчі групи чи креативні гуртки, учасниками яких є члени організації). Зовнішній відтворюється за допомогою соціального капіталу окремих акторів (членів 
організації), які його генерують, або загалом усім колективом (імідж та репутація фірми на ринку). Це можна прослідкувати на рис 2.2.

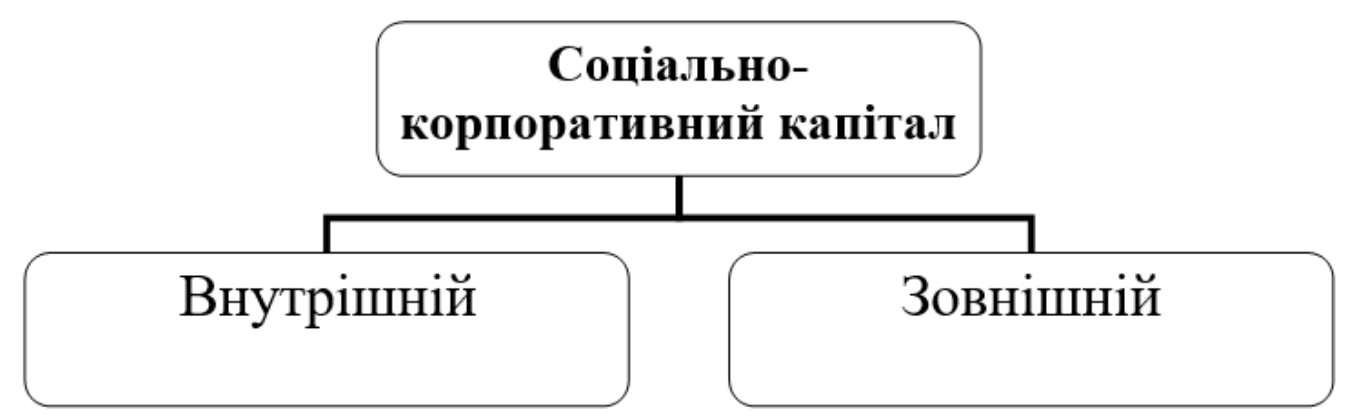

Рис. 15. Структура соціально-корпоративного капіталу Джерело: розроблено автором

Соціально-корпоративний капітал організації $є$ результатом соціалізації кожного члена організації в умовах, які встановлені та підтримуються на цьому підприємстві. Соціалізація забезпечує існування людини в суспільстві і $є$ основою всіх соціальних процесів. Соціалізація в організації відбувається у процесі засвоєння кожним працівником певної організації норм і цінностей, встановлених у ній. Соціалізація на підприємстві (організації) відбувається за допомогою передачі та засвоєння встановлених норм і дотримання правил; формування цінностей у мікросередовищі.

За своєю сутністю соціалізація здебільшого пов'язується 3 формуванням матеріальних передумов до повернення окремих груп населення на шлях активної трудової діяльності [111]. Соціалізація працівників організації відбувається у процесі комунікації та навчання через переймання зразків поведінки, дотримання встановлених норм і цінностей в організації.

Соціалізація кожного члена організації в умовах, затверджених на підприємстві, поліпшує добробут працівника у сфері економічної та позаекономічної діяльності за допомогою можливості індивідуального самовираження.

Соціалізація працівників організації передбачає адаптацію до умов праці та колективу, підвищення рівня професійно-кваліфікаційної підготовки, ефективне 
покращення якості та організаційно-економічних умов праці, розмір доходів i витрат працівників.

Вагомим джерелом формування соціального капіталу на мікрорівні $\epsilon$ різного роду об’єднання громадян, а саме: політичні партії, громадські організації, релігійні організації, профспілки, творчі спілки (інші професійні організації), благодійні організації, об’єднання співтовариств багатоквартирного будинку, органи самоорганізації населення. Група громадян, об’єднана за певними інтересами, матиме більший вплив на вирішення проблемних питань, аніж коли робити це поодинці. Колектив, у якому панує довіра та взаєморозуміння, дає відчуття єдності та захищеності.

Розглянемо динаміку кількості легалізованих об’єднань громадян в Україні протягом 2001-2013 рр. (Додаток Б). Простежується тенденція поступового збільшення таких об’єднань, що позитивно впливає на процес відтворення соціального капіталу країни.

У 2013 році в Україні існувало 3943 легальних об’єднань громадян, 3 них 198 - політичні партії із всеукраїнським статусом і 3745 громадських організацій; у 2012 році їх було 3742, 3 них 194 - політичні партії із всеукраїнським статусом і 3548 громадських організацій.

Учасники громадський об’єднань (організацій), як правило, мають спільну мету і залежать один від одного. Рушієм такого об'єднання і співпраці $\epsilon$ соціальний капітал, який підштовхує людей об’єднуватися в соціальні мережі задля покращення добробуту та якості свого життя і життя суспільства, він $\epsilon$ передумовою соціально-культурного, високорозвиненого суспільства.

Потужний соціально-корпоративний капітал спроможний самоорганізувати і згуртувати членів організації до взаємодії задля досягнення спільних інтересів. Якщо члени організації дотримуються встановлених норм та довіряють одне одному, це веде до зниження виробничих витрат. Коли в колективі панує довіра, можна зекономити на законодавчому регулюванні процесу діяльності організації. Довіра дає можливість розширювати соціальну мережу та співробітництво як в організації, так і за межами їі. 
За різними визначеннями, соціально-корпоративний капітал - це сукупність мережевих, ціннісних, людських та організаційних ресурсів, за допомогою яких відбувається ефективне функціонування будь-якої організації.

Дослідження процесу відтворення соціально-корпоративного капіталу допоможе організаціям ефективно організовувати свою діяльність, збільшити продуктивність праці та ефективність соціально-економічної політики організації, знизити витрати на ведення економічної діяльності.

Соціальні мережі, довіра, норми та цінності - елементи соціальнокорпоративного капіталу, що можуть як ефективно, так і негативно впливати на діяльність організації. Негативний ефект - мережа стає соціальною відповідальністю (боргом) (робить групи ізольованими), позитивний соціально-корпоративний капітал впливає на репутацію та імідж як організації, так і кожного їі працівника, на продуктивне співробітництво, на ефективну командну діяльність, знижує трансакційні витрати, а також впливає на отримання соціальної ренти та інше.

Світова фінансово-економічна криза негативно вплинула на соціальноекономічний розвиток регіонів України. Це призвело до поглиблення багатьох проблем регіонального та державного розвитку. У результаті таких негативних процесів постала потреба в дослідженні та пошуку новітніх способів впливу регіонального соціального капіталу на розвиток як регіону, так і держави загалом.

Система ефективного управління ресурсним потенціалом підприємств дає можливість визначити, які внутрішні його характеристики послаблюють результативність досягнення ефективності в процесі управління. Ефективність досягається за рахунок реалізації послідовних дій, які здійснюються під час управління [213].

Україна сьогодні - це гетерогенний (неоднорідний) соціокультурний простір, у якому на перший план виходить регіональний чинник. Як зазначають американські дослідники, якщо регіон має добре функціонуючу економічну систему і високий рівень політичної інтеграції, то це є результатом успішного 
акумулювання цим регіоном соціального капіталу. У Сполучених Штатах багато соціальних проблем вирішують завдяки наявності та використанню соціального капіталу. Незважаючи на досить велику кількість робіт, присвячених дослідженню регіонального розвитку, недостатньо вивченим є регіональний соціальний капітал. Це питання ми плануємо вирішити.

Регіоном є певна територія, яка представляє собою соціальну систему, що має право на саморозвиток і є невід’ємною частиною єдиного економічного, правового, територіального простору, має свої виняткові особливості, а саме:

- територіальні кордони;

- територіальні органи влади;

- густота населення;

- культурно-історичні особливості, що впливають на погляди і взаємини населення регіону;

- політичні особливості;

- спеціалізацію народного господарства;

- промислову та соціальна інфраструктуру;

- природно-кліматичні умови існування;

- соціальні, політичні, економічні і міжнаціональні відносин, що історично склалися на цій території.

Ці особливості визначають своєрідний характер життя регіонального соціуму, його культури, звичаїв і традицій, релігійних уподобань та інше. Регіон $\epsilon$ комплексом соціальних взаємодій, які утворюють мережу на певному рівні. Кожен регіон має свої характерні ознаки, і цими ознаками виступають такі позаекономічні інститути, як правові, політичні, ідеологічні, етичні.

Соціальне, політичне, правове, економічне, екологічне середовища закладають структуру регіонального простору і сприяють включенню регіону в соціально-економічну, політико-правову сфери на рівні держави. Регіональний розвиток має охоплювати всі сфери життя свого населення задля досягнення 
їхнього добробуту. Це можна зробити за допомогою впровадження регіональних стратегій соціально-економічного розвитку.

На відтворення регіонального соціального капіталу мають вплив: органи державної влади, через дотримання встановлених норм у суспільстві та реалізацію соціальних проектів; політичні партії, через довіру виборців; громадські організації, через мережу зв'язків. Отже, в регіональному соціумі на перший план виступають такі елементи соціального капіталу, що забезпечують процес його відтворення: соціальні мережі, довіра до регіональної влади, громадських організацій, політичних партій та інше, норми і цінності, що забезпечують функціонування регіону. Позаекономічні інститути мають неабиякий вплив на формування соціального капіталу і на сутність соціальноекономічного розвитку країни та її регіонів зокрема.

Соціальний капітал як накопичуваний ціннісний та інституційний ресурс включений у процеси відтворювання і зростання цінностей, суспільних зв'язків, довіри, розвитку особи і культури шляхом взаємної конвертації своїх різноманітних форм, включаючи і економічні. Конвертація означає можливість перетворення одного типу капіталу в іншій. Соціальний капітал не просто «полегшує» виробничу діяльність. Він стає визначальним i, найголовніше, володіє набагато більшим потенціалом порівняно 3 фізичним і людським капіталом. Соціальний капітал незалежно від рівня $\epsilon$ визначним показником економічного зростання i конкурентоспроможності, від нього залежить відтворення всіх інших форм капіталу.

Населення регіону (регіональний соціум) є об'єктом управління, що формується за допомогою економічних $\mathrm{i}$ позаекономічних інститутів. Управління на регіональному рівні здійснюється задля регулювання соціальноекономічних процесів за допомогою соціальної політики, яка забезпечує стабільний розвиток і нормальну життєдіяльність соціуму.

Управління процесом формування і накопичення соціального капіталу на всіх рівнях, зокрема і на регіональному, відбувається через механізм довіри, яка $€$ структурним елементом соціального капіталу й основою побудови як 
економічних, так і позаекономічних відносин. Економіка, суспільство, регіон, ринок не можуть існувати без довіри. Ринок відтворює довіру як певний товар, тому реальною проблемою економіки є досягнення економічної ефективності та оптимального рівня довіри, оскільки довіра знижує трансакційні витрати обміну і збільшує взаємодію у процесі обміну на регіональному рівні.

Проведене в першому розділі дослідження структури соціального капіталу дозволяє розглянути процес його відтворення з позиції регіонального простору (мезорівень).

На регіональному рівні недержавні та громадські організації впливають на розвиток соціального капіталу через мережеве включення (участь в організаціях), рівень міжособистісної довіри, дотримання соціальних норм i цінностей.

Загальний розвиток регіону відбувається за допомогою соціальноекономічної політики, а генератором цього процесу є мережа людей, які мають значний запас індивідуального соціального капіталу і статус у суспільстві.

Мережі соціальних зв’язків у регіональному соціумі мають різний вплив на формування соціального капіталу. Починаючи 3 нанорівня, де соціальний капітал формується на рівні індивіда, можна говорити про те, що кожен індивід має свій запас капіталу, тобто його рівень $є$ неоднаковим. Індивіди з високим рівнем соціального капіталу мають певний статус у суспільстві і мають вагоміші можливості в регулюванні власного розвитку в регіональному соціумі та більший доступ до ресурсів і влади на цьому рівні. Це дає можливість конвертації соціального капіталу в соціальну ренту. Індивіди 3 низьким соціальним капіталом не можуть розраховувати на високий статус у соціумі, тому що цей індивід не може розраховувати на результативні соціальні зв'язки з особами, які мають вищий статус. Проте в такій ситуації винятки також існують і особи 3 низьким статусом вириваються на вищий рівень за допомогою індивідуальних рис характеру (наполегливість, сміливість, комунікабельність, харизматичність та інше). 
Відтворення регіонального соціального капіталу за допомогою позаекономічних інститутів можна охарактеризувати можливістю конвертації економічного капіталу в соціальний через власність, доступ до влади, високий соціальний статус. Слід пам'ятати, що соціально мобільним у цьому процесі конвертації буде індивід з високим соціальним статусом, оскільки він матиме значні можливості для формування максимальних доходів (соціальний капітал, соціальна рента від зв'язків, власність).

У процесі формування регіонального соціального капіталу позаекономічні інститути (правові, політичні, ідеологічні, етичні) за допомогою позаекономічних чинників (ментальність, культура, звички і стереотипи мислення, довіра, освіта, релігія) укріплюють соціальні мережі, які є основою соціального капіталу.

В усіх сферах людських відносин, зокрема й на регіональному рівні, має місце такий позаекономічний чинник, як довіра, оскільки довіра є соціальноекономічним механізмом, що забезпечує соціальний розвиток. На регіональному рівні вона виступає як один з факторів, що підтримує інтегрованість і стійкість регіону, вона бере участь у конструюванні горизонтальних і вертикальних зв'язків, є умовою виникнення на мезорівні різних об'єднань, асоціацій. 